\title{
Mapping the physico-chemical properties of mineral dust in western Africa: mineralogical composition
}

\author{
P. Formenti ${ }^{1}$, S. Caquineau ${ }^{2}$, K. Desboeufs ${ }^{1}$, A. Klaver ${ }^{1}$, S. Chevaillier ${ }^{1}$, E. Journet ${ }^{1}$, and J. L. Rajot ${ }^{1,3}$ \\ ${ }^{1}$ LISA, UMR CNRS7583, Université Paris Est Créteil et Université Paris Diderot, Institut Pierre Simon Laplace, \\ Créteil, France \\ ${ }^{2}$ IPSL/LOCEAN, UMR 7159 - IRD-CNRS-UPMC-MNHN, Institut de Recherche pour le Développement, Bondy, France \\ ${ }^{3}$ IEES, UMR IRD 242 - IRD - UPMC - CNRS - UPEC - AgroParisTech, Bondy, France
}

Correspondence to: P. Formenti (paola.formenti@lisa.u-pec.fr)

Received: 7 March 2014 - Published in Atmos. Chem. Phys. Discuss.: 23 April 2014

Revised: 30 July 2014 - Accepted: 27 August 2014 - Published: 10 October 2014

\begin{abstract}
In the last few years, several ground-based and airborne field campaigns have allowed the exploration of the properties and impacts of mineral dust in western Africa, one of the major emission and transport areas worldwide. In this paper, we explore the synthesis of these observations to provide a large-scale quantitative view of the mineralogical composition and its variability according to source region and time after transport.

This work reveals that mineral dust in western Africa is a mixture of clays, quartz, iron and titanium oxides, representing at least $92 \%$ of the dust mass. Calcite ranged between 0.3 and $8.4 \%$ of the dust mass, depending on the origin. Our data do not show a systematic dependence of the dust mineralogical composition on origin; this is to be the case as, in most of the instances, the data represent the composition of the atmospheric burden after 1-2 days after emission, when air masses mix and give rise to a more uniform dust load. This has implications for the representation of the mineral dust composition in regional and global circulation models and in satellite retrievals.

Iron oxides account for $58 \pm 7 \%$ of the mass of elemental Fe and for between 2 and $5 \%$ of the dust mass. Most of them are composed of goethite, representing between 52 and $78 \%$ of the iron oxide mass. We estimate that titanium oxides account for $1-2 \%$ of the dust mass, depending on whether the dust is of Saharan or Sahelian origin.

The mineralogical composition is a critical parameter for estimating the radiative and biogeochemical impact of mineral dust. The results regarding dust composition have been
\end{abstract}

used to estimate the optical properties as well as the iron fractional solubility of Saharan and Sahelian dust.

Data presented in this paper are provided in numerical form upon email request while they are being turned into a public database, the Dust-Mapped Archived Properties (DUST-MAP), which is an open repository for compositional data from other source regions in Africa and worldwide.

\section{Introduction}

Mineral dust from wind-driven soil erosion is an important player in the climate system. It is emitted in large quantities from arid and semi-arid regions of the globe, mostly Africa, Asia, Australia and North America (Shao et al., 2011), accounting for about $2000 \mathrm{Mt}$ to the annual global aerosol emissions. Once in the atmosphere, mineral dust has several climatic and environmental impacts, related to its ability to scatter and absorb radiation (both in the solar and the terrestrial spectrum) to act as giant cloud and ice nuclei, to alter the concentrations of some gaseous pollutants (such as ozone) and to provide nutrients to the ecosystems via dry and wet deposition, whereby also changing the surface albedo (Shao et al., 2011; Mahowald et al., 2011). The relevance of these phenomena can be expressed in terms of radiative forcing, whose magnitude, in terms of central values, is estimated to be as high as $0.5-1 \mathrm{~W} \mathrm{~m}^{-2}$ on the global scale (Mahowald et al., 2011). However, uncertainties remain important because of the spatial heterogeneity of concentrations, 
due to localised emission and short residence time in the atmosphere ( 1 week at the most, depending on particle size) but also because of the far from satisfactory knowledge of the underlying physico-chemical properties, composition, size and shape ruling the optical, chemical and physical interactions of mineral dust with radiation and the atmospheric, terrestrial or oceanic constituents (Formenti et al., 2011a). This is particularly the case with regard to composition. Dust is made of different minerals, whose proportions, at emission, depend on the mineralogy of the source region and surface wind speed relative to the soil roughness, which determines their size distribution (Marticorena and Bergametti, 1995; Alfaro et al., 1998). The various minerals - clays, quartz, potassic and sodic feldspars, calcium-rich carbonates and sulphates, iron and titanium oxides - have different mineralogical and crystallographic properties; therefore, they may act differently with respect to light extinction, absorption of water and surface reactivity (Pye, 1987). For example, iron oxides have been shown to control the interaction with light in the UVvisible spectrum (Sokolik and Toon, 1999), whereas quartz, clays and Ca-rich carbonates become important when looking at the infrared part of the radiation spectrum (Sokolik et al., 1998). Clays, but also feldspars, come in to play when it comes to investigating the capacity of dust to act as ice nuclei at low temperature (Hoose et al., 2008; Atkinson et al., 2013), whereas calcite (calcium carbonate) shows high surface reactivity with respect to various atmospheric pollutants (Crowley et al., 2010). Another clay family, the smectites, bears the most soluble iron which might become available as a nutrient to marine phytoplankton (Journet et al., 2008). The properties of mineral dust are size-dependent, and the dimensional spectrum of mineral dust particles at emission extends over various orders of magnitude from approximately 200-300 nm to $100 \mu \mathrm{m}$ (Kandler et al., 2009), depending on wind speed at emission. As a consequence, the properties of mineral dust vary as a function of time after emission due to size-dependent deposition, mixing and gaseous condensation. Because these processes are not well established, the physico-chemical properties of mineral dust have to be determined experimentally at the various times of their life cycle. In this paper, we relate the mineralogical and chemical composition of mineral dust from western Africa at emission or at most within 1-2 days from emission. The southern Sahara is the location of two of the most persistent dust sources on the global scale: the Bodélé depression in between the Tibesti and the Ennedi mountain chains in Chad and the areas in between the east of Mauritania, the north of Mali and the south of Algeria (Prospero et al., 2002; Laurent et al., 2008; Washington et al., 2006; Shao et al., 2011). These sources are relevant on the global scale as their emissions are transported across the Atlantic Ocean towards South and Central America (Reid et al., 2003; Koren et al., 2006; Ben-Ami et al., 2009, 2010).

The atmospheric content of mineral dust in western Africa shows a very pronounced seasonal cycle despite high vari- ability, both on the daily and interannual scales (N'Tchayi et al., 1994, 1997; Goudie and Middleton, 2001). This is largely explained by the alternance of two meteorological regimes. Throughout the year, the "Harmattan", a north-eastern dry wind, is responsible for intense dust emissions in the arid areas of the Sahara and very efficient transport towards the Atlantic Ocean and across the Sahel (Pye, 1987; Sokolik et al., 2001; Laurent et al., 2008). Wintertime is also the biomass burning season south of approximately $13^{\circ} \mathrm{N}$ (Haywood et al., 2008), and mixing between dust and biomass burning aerosols might occur during southward transport (Johnson et al., 2008). During summer, the Intertropical Convergence Zone (ITCZ) displaces northward, allowing the surface monsoon flow to intrude into the continent from the south-west towards the continental Sahel. This shift induces a progressive organisation of convection from isolated cells to largescale, quickly propagating systems, which, particularly at the beginning of the monsoon season, often do not precipitate and are efficient in eroding bare soils and producing mineral dust (Marticorena et al., 2010; Abdourhamane Touré et al., 2011). The summertime column dust content over western Africa results, therefore, from the superimposition of local emission from the Sahel and remote transport of dust emitted in the Sahara (Tegen and Fung, 1994; Yoshioka et al., 2005; Marticorena et al., 2010).

The mineralogy of the Saharan and Sahelian source areas is different: the Sahara is mainly composed of Calcisols or Arenosols, whereas the Sahel is richer in weathered Plinthosols (Fe oxides, kaolinite, quartz) (Pye, 1987; Claquin et al., 1999; Caquineau et al., 2002; Nickovic et al., 2012; Journet et al., 2014). As a consequence, mixing or layering of dust transported from the Sahara and that emitted locally by convection over the Sahel should be detectable through differences in the composition over the atmospheric column.

Furthermore, western Africa is prone to land-use change because of the rapid demographic increase and desertification during drought periods (ECA, 2005; Dai, 2011), which could feed back as increased emissions (Carslaw et al., 2010). Rajot (2001) has shown that, in the Sahel, additional emission by wind erosion by mesoscale meteorological disturbances, such as organised convective systems, occurs on harvested soils only. These additional emissions, anthropogenic in origin, are not quantified to date (Boucher et al., 2013). To provide the quantitative estimate of the mineralogical composition of mineral dust on a regional scale, we report in this paper the synthesis of data from various aircraft and ground-based field campaigns which took place in western Africa in 2006 and 2007. These are the African Monsoon Multidisciplinary Analysis (AMMA) special observing period 0 (SOP0; Rajot et al., 2008), augmented by the airborne Dust and Biomass-burning Experiment (DABEX; Haywood et al., 2008); special observing periods 1 and 2 (SOP1-2; Reeves et al., 2010); the Dust Outflow and Deposition to the Ocean (DODO; McConnell et al., 2008) and the Geostationary Earth Radiation Budget Intercomparison of Longwave 
and Shortwave radiation (GERBILS; Haywood et al., 2011). Some of the data discussed in this paper have been published previously (Formenti et al., 2008, 2011b; Rajot et al., 2008; Klaver et al., 2011). Here, they are revisited with a broader discussion of the mineralogical variability on the regional scale of western Africa and its implications for climate. This paper discusses whether, when mapped on the scale of western Africa, the regional variability in emission, deriving from the heterogeneity of the mineralogy of the parent soils, is still relevant or whether it becomes irrelevant when dust is airborne. This is important for developing a model parameterisation for dust in regional and global climate models or for satellite retrieval algorithms.

\section{Methods}

Full details of the field campaign operations, experimental procedures, collection and analytical protocols are described in a number of companion papers (Hawyood et al., 2008, 2011; Formenti et al., 2008, 2011b; Rajot et al., 2008; McConnell et al., 2008, 2010; Klaver et al., 2011), which are summarised below.

\subsection{Field campaigns}

AMMA was an international project to improve our knowledge and understanding of the West African monsoon (WAM), its variability on daily-to-interannual timescales and its effects on the state of the atmosphere (Redelsperger et al., 2006). Because of their links to precipitation, wind speed, soil surface state and drought at different timescales, mineral dust aerosols play a role in this comprehensive scientific framework.

The experimental strategy of the AMMA program was based on embedded multiyear, seasonal and intensive observation periods (Janicot et al., 2008; Lebel et al., 2010). The observations used in this paper were conducted during the intensive observations periods, called special observing periods (SOPs). The wintertime SOP (SOP0), was dedicated to the investigation of mineral dust and biomass burning, and their mixing; it took place between 13 January and 13 February 2006. The summertime observations (periods SOP1 and SOP2) started on 31 May 2006 and ended on 17 July 2006 and were dedicated to the detailed description of the interactions between aerosols and convection.

The ground-based observations were conducted at the AMMA supersite of Banizoumbou $\left(13.5^{\circ} \mathrm{N}, 2.6^{\circ} \mathrm{E} ; 250 \mathrm{~m}\right.$ above sea level), situated in a remote location about $60 \mathrm{~km}$ east from the capital of Niger, Niamey. This site has been operational since the early 1990s, when the first measurements of soil erosion were performed on a cultivated field and a fallow (Rajot, 2001). Since 1995, the site has also been an Aerosol Robotic Network (AERONET) station, measuring columnar aerosol optical properties. The ground-based site operations are fully described in Rajot et al. (2008).

The aircraft observations were conducted from Niamey, Niger. The wintertime airborne campaign, called AMMA SOPO-DABEX, was conducted onboard the Facility for Airborne Atmospheric Measurements (FAAM) BAe-146 aircraft (Haywood et al., 2008). The aircraft performed 13 research flights in the area between 8 and $18^{\circ} \mathrm{N}$, including three dedicated excursion to the north of Niger, toward the Aïr Mountains and the Ténéré desert, to probe specifically mineral dust which was being transported. In summertime, the observations were conducted onboard the Service des Avions Français Instruments pour la Recherche en Environnement (SAFIRE) ATR-42, which operated 20 research flights in the area between 6 and $20^{\circ} \mathrm{N}$, thus crossing the ITCZ to the north; this was done in order to contrast the Sahara and the Sahelian dust properties in their respective boundary layers (Reeves et al., 2010; Formenti et al., 2011b).

The GERBILS derived its scientific motivation from the discrepancy that had been found between the satellite observations and the numerical weather model predictions of the top-of-the-atmosphere outgoing long-wave radiation over desert areas in western Africa (Haywood et al., 2005). This discrepancy could be reconciled by including mineral dust in the model. The GERBILS experiment, whose full rationale and operating details are described in Haywood et al. (2011), was therefore designed to test this hypothesis, and to determine the properties of the mineral dust to be included in the model. The experiment consisted of 10 research flights onboard the FAAM BAe-146, performed between Nouakchott $\left(18.10^{\circ} \mathrm{N}, 15.94^{\circ} \mathrm{W}\right.$; Mauritania) and $\mathrm{Ni}-$ amey $\left(13.48^{\circ} \mathrm{N}, 2.18^{\circ} \mathrm{E}\right.$; Niger) on an almost constant route along the $18^{\circ} \mathrm{N}$ meridian. Flights were performed between 18 and 29 June 2007 , a period characterised by a persistent and widespread dust load.

Finally, the DODO airborne experiment took place at two different periods in 2006: in wintertime (7-16 February) and in summertime (22-28 August). The aim of DODO was to characterise dust as a possible nutrient for the marine ecosystems. For this reason, the FAAM BAe-146 aircraft was based in Dakar, in Senegal, and most of the 12 research flights (6 in the winter period and 6 in the summer period) were conducted over the Atlantic Ocean in the outflow from the African continent. However, two flights, one per season, were carried out inland above Mauritania in order to sample dust at or very close after emission (McConnell et al., 2008).

\subsection{Sample collection and handling}

\subsubsection{Ground-based}

Aerosol sampling at the ground-based AMMA supersite of Banizoumbou was performed using two identical, purposebuilt, wind-oriented inlets designed for the AMMA field campaigns (Rajot et al., 2008). By using the standard 
formulae of particle losses in inlets and tubings reported in Baron and Willeke (2001) and Hinds (1999), the cut-off diameter $(50 \%)$ efficiency of these inlets has been calculated to be approximately $40 \mu \mathrm{m}$. Each inlet leads to a sampling chamber containing seven different sampling lines, each of them dedicated to a different instrument. Multiple sampling lines are very convenient as they allow collecting various filter samples in parallel (differentiated and optimized in terms of sampling medium), exposure interval and flow rate as a function of the analytical technique to be applied. This also results in minimal manipulation of the filters after sampling. Samples were collected on acid-washed, $42 \mathrm{~mm}$ polycarbonate Nuclepore filters $(0.4 \mu \mathrm{m}$ pore size $)$ mounted on plastic rings. Samples were stored in Petri dishes after sampling. Sampling time was of the order of hours and was varied depending on the aerosol mass concentration measured on-line by a tapered element oscillating microbalance (TEOM; Rupprecht and Patashnick, Albany, USA) (Rajot et al., 2008).

\subsubsection{Airborne}

During the AMMA SOP0-DABEX, DODO and GERBILS campaigns, samples were collected onboard the FAAM BAe146 aircraft. The aircraft is capable of carrying 2 crew, 18 scientists and a total scientific payload of up to $4000 \mathrm{~kg}$ for a distance of $3700 \mathrm{~km}$ with a ceiling of 35000 feet and has a typical science speed of $110 \mathrm{~m} \mathrm{~s}^{-1}$. For the typical scientific payload, flight patterns, ambient meteorological conditions and the proximity of diversion airports encountered during the campaigns, the average endurance of the BAe146 aircraft was approximately $5 \mathrm{~h}$. Sampling was performed using a set of two parallel thin-walled inlet nozzles with a curved leading edge; the design was based on criteria for aircraft engine intakes at low Mach numbers (Andreae et al., 1988). The sampling system was operated at flow rates that averaged $120 \mathrm{~L} \mathrm{~min}^{-1}$ (at ambient pressure and temperature). The flow was adjusted to maintain slightly subisokinetic sampling conditions. The passing efficiency of the inlets has not been formally quantified. During AMMA SOP0/DABEX, Chou et al. (2008) showed that the number size distributions of the aerosols collected on the filters (counted by electron microscopy) extended up to $10 \mu \mathrm{m}$ diameters and were of comparable magnitude to those measured by wingmounted optical counters.

Aerosol particles were sampled by filtration through two stacked-filter units (SFUs) mounted in parallel. Each SFU can hold a maximum of three filters on sequential 47 or $90 \mathrm{~mm}$ diameter polyethylene supports. Only one stage was used during the campaigns, i.e. samples represented the aerosol bulk composition. Samples were collected only during horizontal flight legs lasting not less than $20 \mathrm{~min}$ in order to guarantee sufficient loading of the filter samples. As a consequence, at the aircraft cruise speed, each sample had, at best, a spatial resolution of $180 \mathrm{~km}$. Each SFU consisted of a Nuclepore filter (Whatman) of nominal pore size $0.4 \mu \mathrm{m}$.
During the AMMA SOP1-2 campaigns, samples were collected onboard the SAFIRE ATR-42. With the necessary payload for the campaign, the aircraft had a maximum endurance of $4 \mathrm{~h}$. Minimum flight altitude was $300 \mathrm{~m}$ over land. The ceiling was approximately $7 \mathrm{~km}$. The aircraft was equipped with basic sensors for measuring the radiative, dynamic and thermodynamic properties of the atmosphere (Said et al., 2010).

Aerosol sampling was performed using the AVIRAD aerosol sampling system, newly developed for AMMA (Formenti et al., 2011b). It consists of an isoaxial and isokinetic inlet whose $50 \%$ passing efficiency has been estimated to be $9 \mu \mathrm{m}$ in diameter. At the cruise speed of the ATR-42 $\left(93 \mathrm{~m} \mathrm{~s}^{-1}\right)$ the delivered volumetric flow rate is $350 \mathrm{~L} \mathrm{~min}^{-1}$, which was distributed to various instruments, including two SFU for collecting bulk aerosol samples. Samples were obtained by parallel filtration through $42 \mathrm{~mm}$ diameter polycarbonate membranes (nominal pore size $0.4 \mu \mathrm{m}$, Nuclepore, Whatman) on polyethylene supports. Samples were collected only during horizontal flight legs lasting no less than $20 \mathrm{~min}$. Immediately after each flight, the loaded filters were stored in Petri dishes.

Ground-based operation with multiple sampling lines allowed for parallel sampling where the sampling duration was adapted to the characteristics (detection limit, saturation level) of the technique to be employed for analysis. On the aircraft, the two parallel samples available had to be manipulated further to allow the number of analyses one wanted to perform, also taking into account the fact that some analyses are destructive of the sample. Therefore, the handling protocol for aircraft samples consisted of analysing entire filters or portions thereof, depending on their load of mineral dust. A dedicated tool in polyethylene has been developed for cutting the 47 or $90 \mathrm{~mm}$ filters into halves, quarters or eighth without touching and, therefore, contaminating them.

\subsection{Sample analysis}

\subsubsection{Elemental composition}

The total elemental concentrations for elements from $\mathrm{Na}$ to $\mathrm{Pb}$ were measured by wavelength dispersive $\mathrm{X}$-ray fluorescence (WD-XRF) for samples collected on the ground and on the ATR-42 and particle-induced X-ray emission (PIXE) for the aircraft samples collected onboard the BAe-146. The reason for using different techniques for ground-based and aircraft samples is the fact that the WD-XRF sample holder set-up could not, at the time, host filters which are not supported on polyethylene frames. The details of the analytical protocols are provided in Formenti et al. (2008, 2011b), McConnell et al. (2008), Rajot et al. (2008) and Klaver et al. (2011). Elemental concentrations are estimated with a $5 \%$ error. An intercomparison exercise on samples generated in the laboratory from geo-standards of known and certified 
Table 1. Calibration coefficients by mineral, obtained from the calibration of the XRD analyser used in this study. The calibration coefficients represent the slope of the linear correlation between the number of diffracted counts by unit mass. The origin of the standard minerals used in this study are also reported. The absolute uncertainty of the slope is also indicated, whereas numbers in parentheses are the percent uncertainty, obtained as a ratio between the absolute uncertainty and slope value.

\begin{tabular}{llrc}
\hline Mineral & Origin & Slope $(\mathrm{cps} \mathrm{mg}$ & \\
\hline Quartz $\left(\mathrm{SiO}_{2}\right)$ & Fontainebleau, France & $446 \pm 14(3 \%)$ & 0.88 \\
Calcite $\left(\mathrm{CaCO}_{3}\right)$ & Bédarieux, France & $325 \pm 11(3 \%)$ & 0.94 \\
Dolomite $\left(\mathrm{CaMg}^{2}(\mathrm{CO} 3)_{2}\right)$ & Traversella, Italy & $679 \pm 70(10 \%)$ & 0.55 \\
Gypsum $\left(\mathrm{CaSO}_{4} 2 \mathrm{H}_{2} \mathrm{O}\right)$ & Unknown & $446 \pm 22(5 \%)$ & 0.89 \\
Orthoclase $\left(\mathrm{KAlSi}_{3} \mathrm{O}_{8}\right)$ & Madagascar & $997 \pm 70(7 \%)$ & 0.69 \\
Albite $\left(\mathrm{NaAlSi}_{3} \mathrm{O}_{8}\right)$ & Ontario, Canada & $2456 \pm 56(2 \%)$ & 0.96 \\
\hline
\end{tabular}

composition has shown that the two techniques yield comparable results within the error bars (Formenti et al., 2010).

\subsubsection{Mineralogical composition}

The identification of the major minerals making up mineral dust (quartz $\left(\mathrm{SiO}_{2}\right)$, calcite $\left(\mathrm{CaCO}_{3}\right)$, dolomite $\left(\mathrm{CaMg}\left(\mathrm{CO}_{3}\right)_{2}\right.$, gypsum $\left(\mathrm{CaSO}_{4} \cdot 2 \mathrm{H}_{2} \mathrm{O}\right)$, clays (kaolinite, illite, smectite, chlorite), feldspars (orthoclase $\mathrm{KAlSi}_{3} \mathrm{O}_{8}$ and albite $\left.\mathrm{NaAlSi}_{3} \mathrm{O}_{8}\right)$ ) was performed by X-ray diffraction (XRD) analysis at the Institut de Recherche pour le Développement (IRD) in Bondy, France. The diffractometer, a Siemens D500 with Ni-filtered $\mathrm{Cu}-\mathrm{K}_{\alpha}$ radiation, was operated at $40 \mathrm{kV}$ and $30 \mathrm{~mA}$. Samples were scanned from 2 to $70^{\circ}(2 \theta)$ in steps of 0.02 . The analytical procedure and semi-quantitative treatment are fully described by Caquineau et al. (1997), who adapted the sample preparation to lowmass mineral aerosol (load deposited on filter $>800 \mu \mathrm{g}$ ). The calibration protocol that was applied to the XRD spectrometer in order to quantify the mineralogical composition is described in Klaver et al. (2011). The calibration curves were improved after publication of the Klaver et al. (2011) paper by calibrating the feldspars (orthoclase and albite). The calibration factors $K_{i}$, representing the ratio between the peak surface area $S_{i}$ in the diffraction spectra and the mass $m_{i}$ of the $i$ mineral, are reported in Table 1 . The error in the mineral masses is estimated as the sum of the relative error in the peak area in the diffractograms and in the calibration factor $K_{i}: \frac{\Delta m_{i}}{m_{i}}=\frac{\Delta K_{i}}{K_{i}}+\frac{\Delta S_{i}}{S_{i}}$. The term $\Delta K_{i} / K_{i}$ is estimated from the error in the slope of the calibration curve (Table 1), and it varies between 2 and $10 \%$. The term $\Delta S_{i} / S_{i}$ depends on the abundance of the mineral in the samples and has been estimated from the counting statistics obtained.

\subsubsection{Iron oxide content and speciation}

The iron oxide content, defined as the fraction of iron which is not in the crystal lattice of silicates (Karickhoff and Bailey, 1973), was determined with the adapted citrate-bicarbonatedithionite (CBD) extraction method developed by Lafon et al. (2004). This method is an adaptation for aerosol filters (with typical material mass less than $500 \mu \mathrm{g}$ ) of the classical method of Mehra and Jackson (1960) for soil analysis. The method uses a reagent to dissolve iron oxides selectively via reduction. Details of this analysis are given in Formenti et al. (2008, 2011b) and Klaver et al. (2011). The percent error in the iron oxide content is estimated to be $10 \%$ as its assessment is based on two XRF analyses (prior to and after dissolution of the iron oxides from the sample).

The speciation of iron oxides was performed by $\mathrm{X}$-ray absorption (XAS) in the $\mathrm{Fe} \mathrm{K}$ range: XANES (X-ray absorption near-edge structure) and EXAFS (extended X-ray absorption fine structure) at the SAMBA (Spectroscopies Applied to Materials based on Absorption, http://www.synchrotron-soleil.fr/portal/page/portal/ Recherche/LignesLumiere/SAMBA) beam line SOLEIL synchrotron facility in Saclay, France. XAS spectroscopy is based on the analysis of the position and shape of the $\mathrm{K}$ pre-edge and edge peaks, depending on the oxidation state of iron but also on the atomic position of the neighbouring atoms, mostly $\mathrm{O}^{+}$and $\mathrm{OH}^{-}$. The quantification of the $\mathrm{Fe}$ status was based on the analysis of five standards of $\mathrm{Fe}(\mathrm{III})$-bearing minerals which can be found in mineral dust. Full details of the experimental protocols and the data analysis are provided in Formenti et al. (2014).

\subsection{Data interpretation and presentation}

\subsubsection{Source identification}

The identification of source regions has been performed using a variety of ancillary products:

1. the record of measurements of the horizontal movement of sand grains by a saltiphone (Eijkelkamp, Giesbeek, the Netherlands) located in proximity to the sampling inlets at the supersite of Banizoumbou and providing the estimate of the saltation horizontal flux related to established local erosion (Sow et al., 2009);

2. various satellite products, in particular, the daily images of the UV aerosol index by the Ozone Monitoring Instrument (OMI) on Aura, the instantaneous dust product 
maps from the SEVIRI instrument on the MSG satellite and the Infrared Difference Dust Index (IDDI) obtained from the infrared channel of Meteosat $(10.5-12.5 \mu \mathrm{m})$ (Legrand et al., 1994);

3. back trajectories and air mass dispersion calculations using the Met Office Numerical Atmosphericdispersion Modelling Environment (NAME; Cullen, 1993) and the NOAA HYbrid Single-Particle Lagrangian Integrated Trajectory Model (HYSPLIT) as described in Chou et al. (2008), Rajot et al. (2008) and Klaver et al. (2011).

\subsubsection{Data presentation}

\section{Calculation of the total mass}

In the following, the composition of mineral dust will be presented as a percentage of the total dust mass (TDM). According to Pye (1987), the TDM can be decomposed as

$$
\begin{aligned}
\mathrm{TDM} & =m_{\text {clays }}+m_{\text {quartz }}+m_{\text {Ca-rich }}+m_{\text {feldspars }} \\
& +m_{\text {iron oxides }}+m_{\text {tit oxides }}+m_{\text {organic }}
\end{aligned}
$$

where $m_{\text {clays }}$ is the mass of the major clay species (kaolinite, illite, smectite, chlorite); $m_{\text {quartz }}$ is the mass of quartz $\left(\mathrm{SiO}_{2}\right) ; m_{\text {Ca-rich }}=m_{\text {calc }}+m_{\text {dolom }}+m_{\text {gypsum }}$ is the mass of calcium carbonates and sulfates in the form of calcite $\left(\mathrm{CaCO}_{3}\right)$, dolomite $\left(\mathrm{CaMg}\left(\mathrm{CO}_{3}\right)_{2}\right)$ and gypsum $\left(\mathrm{CaSO}_{4}\right)$; $m_{\text {feldspars }}$ is the mass of feldspars, such as albite and orthoclase ( $\mathrm{NaAlSi}_{3} \mathrm{O}_{8}$ and $\mathrm{KAlSi}_{3} \mathrm{O}_{8}$, respectively); $m_{\text {iron oxides }}$ is the mass of hematite $\left(\alpha-\mathrm{Fe}_{2} \mathrm{O}_{3}\right)$ and goethite $(\alpha-\mathrm{FeOOH})$; $m_{\text {tit oxides }}$ is the mass of titanium oxides $\left(\mathrm{TiO}_{2}\right)$; and $m_{\text {organic }}$ is the mass of organic matter which is present in the soils as biological debris and complex organic molecules (humus).

In practical terms, the TDM can be approximated by the TEDM (total estimated dust mass) as the sum of oxides corresponding to the major elements in mineral dust $\left(\mathrm{Al}_{2} \mathrm{O}_{3}\right.$, $\mathrm{SiO}_{2}, \mathrm{Fe}_{2} \mathrm{O}_{3}, \mathrm{CaCO}_{3}, \mathrm{~K}_{2} \mathrm{O}$ and $\mathrm{Ti}_{2} \mathrm{O}$ ) whose masses are measured by XRF analysis. The TEDM estimated in this way can be compared to the direct measurement of the total dry gravimetric mass (TDGM) (which is available for some of the data sets (ground-based AMMA SOP0 and SOP1-2 and GERBILS)), either by weighing or by on-line Tapering Element Oscillating Microbalance (TEOM, model 1400a, Rupprecht and Patashnick Albany, New York, USA) (see Rajot et al., 2008; Klaver et al., 2011).

The slope of the least-squared linear regression between the TEDM and TDGM, calculated for the 81 samples for which the extraction of iron oxides was performed (see Sect. 3.3), is 0.98 and the coefficient of determination $\left(R^{2}\right)$ is 0.88 . This is very satisfactory, taking into account that, because the mass is dominated by coarse particles, which have a large mass but small number, differences might arise through the loss of some coarse particles between the time at which the filter was weighed and the time at which it was analysed

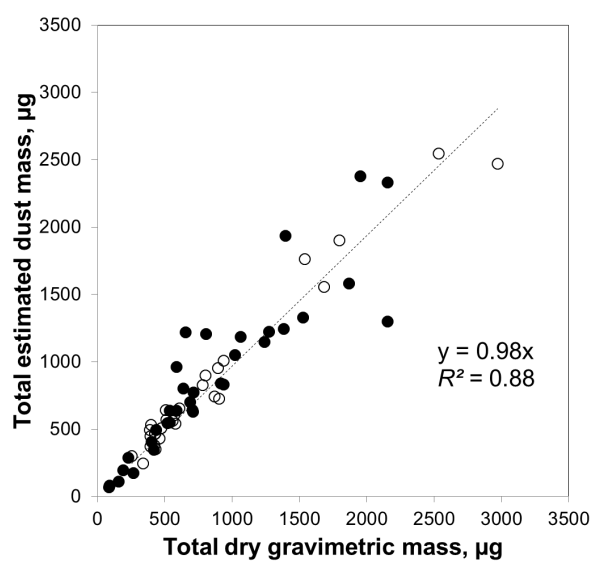

Dry season

- Wet season

Figure 1. Comparison between the total estimated dust mass (TEDM) estimated from the chemical composition and the total dry gravimetric mass (TDGM) for the AMMA SOP0 (dry season, open circles) and AMMA SOP1-2 data (wet season, black circles). The dashed line represents the slope of the calculated linear regression.

by XRF or by small differences between the filter sampling duration and the TEOM integration times. As a matter of fact, most of the scatter in the data is observed for samples which corresponded to local erosion or transported emission by convective systems and which had the largest fraction of coarse particles and the shortest integration times. This becomes apparent the ground-based AMMA SOP0 and SOP12 data (Fig. 1) are plotted separately.

Therefore, we consider that the TDM is equal to the TDGM for samples for which the TDGM is measured. When this is not available, the TDM is approximated via the TEDM, calculated as the sum of oxides. The percent uncertainty is calculated as the squared sum of the errors in the calculation of the TEDM from the measured $\mathrm{Al}, \mathrm{Si}, \mathrm{Fe}, \mathrm{Ca}$, $\mathrm{K}$ and $\mathrm{Ti}$ elemental masses. In this way, the percent uncertainty in the TDM comes to $12 \%$.

\section{Calculation of the mineralogical composition}

The mass apportionment presented in Eq. (1) has been performed as follows:

1. The masses of quartz, calcite, dolomite, gypsum and feldspar ( $\left.m_{\text {quartz }}, m_{\text {Ca-rich }}, m_{\text {feldspars }}\right)$ were quantified by XRD using the mass/intensity calibration curves as described in Sect. 2.3.

2. The mass of iron oxides ( $\left.m_{\text {iron oxides }}\right)$ was measured directly by CBD analysis. The division of $m_{\text {iron oxides into }}$ its main components (hematite and goethite) was performed by XANES spectroscopy.

3. The mass of the clay species, kaolinite, illite, smectite and chlorite ( $\left.m_{\text {clays }}\right)$ was estimated by the difference between the TDM and the sum of the masses of $m_{\text {quartz }}$, 
$m_{\text {Ca-rich }}, m_{\text {feldspars }}$ and $m_{\text {iron oxides. }}$ The division of $m_{\text {clays }}$ into its constituent species is difficult to achieve without a direct calibration. This calibration is highly uncertain as there is basically no mineralogical reference with the same crystallographic and chemical status as in the actual aerosol samples because of the exposure to the environment, weathering in particular, that they experience before and after becoming airborne. Furthermore, smectite clays are actually a family of species with different chemical characteristics. When only illite and kaolinite are present in the samples and no traces of chlorite or smectite are shown by XRD analysis, their mass can be apportioned readily using the illite-to-kaolinite ratios (I/K) established by Caquineau et al. (2002) as a function of dust source region as

$$
\begin{aligned}
& m_{\text {kaolinite }}=\frac{m_{\text {clays }}}{1+\frac{1}{\mathrm{~K}}}, \\
& m_{\text {illite }}=m_{\text {clays }}-m_{\text {kaolinite }} \cdot
\end{aligned}
$$

When smectites or chlorite are also detected, Eq. (2) does not hold true. In the following sections, we will evaluate the uncertainties induced by this approximation.

4. The mass of titanium oxides $m_{\text {tit oxides }}$ was estimated by calculating the $\mathrm{TiO}_{2}$ contribution as the measured elemental $\mathrm{Ti}$ multiplied by 1.67 , the ratio between the atomic weight of $\mathrm{TiO}_{2}$ and that of elemental $\mathrm{Ti}$.

5. The mass of organic compounds $\left(m_{\text {organic }}\right)$ in mineral dust was generally ignored on the basis of the work by Lepple and Brine (1976); it should not exceed $3 \%$ of the TDM.

6. We also did not take into account the mass of diatomite fragments which have been observed in samples originating from Bodélé (Chou et al., 2008). Diatomite fragments are silicate skeletons of algae and they do not have a crystalline structure which can be quantified by XRD analysis. Their presence can be proven by elemental analysis showing excessive values of the Si-to-Al ratio as high as 4 (Formenti et al., 2011b). The diatomite mass can, therefore, be estimated by comparing the excess $\mathrm{SiO}_{2}$ mass calculated from elemental Si concentrations with respect to the mean ratio to $\mathrm{Al}$ to the mass of quartz estimated by XRD analysis. When doing so, the excess $\mathrm{SiO}_{2}$ mass is comparable to that of quartz except for the few samples for which dust originated from the Bodélé depression; in this case their contribution to the TDGM is in the range 6-13\%. This contribution is accounted for in the error bars of the clay fraction for these samples.

\section{Results}

The whole data set (ground-based and airborne AMMA SOP0 and AMMA SOP1-2, GERBILS and DODO campaigns) consists of 704 samples, for which we measured the total elemental composition. Out of this total, 54 samples have been selected to provide data on the major mineral composition, 86 have been analysed to provide the content of iron oxide and 12 to determine the iron oxide speciation. 31 samples combined sufficient information to determine the full mineralogical composition. The sample selection has been based on the filter loading and on the possibility of identifying the samples' provenance and attributing a source region to them.

\subsection{Identification of source regions}

Identifying the origin of the mineral dust collected on the samples implies that one is able to make the link between the knowledge of the position and the mineralogy of the source regions and that of the aerosol samples. To do so, one must know (1) the transfer function, at emission, linking the soil mineralogical/chemical composition to that of the aerosols and (2) the transfer function describing how its composition is modified during transport.

The first transfer function describes the mineralogical fractionation that occurs between the soil and the aerosol as a consequence of the size segregation that happens when the soil grains saltate on the soil surface (Rahn, 1976). The fractionation can alter the elemental ratio between $\mathrm{Si}$ and $\mathrm{Al}$ as a result of the depletion, at emission, in quartz and feldspars with respect to clays. Quartz and feldspars have higher Si content than clays and are more abundant in the sand than in the silt/clay fractions of the soil (Mason, 1966; Rahn, 1976; Chatenet et al., 1996). The latter are enhanced during emission by saltation/sandblasting (Alfaro et al., 1998). Whereas there is still no systematic assessment of the transfer function between the soil and the aerosol composition, Claquin et al. (1999) have shown that some mass ratios between minerals (for example, that of illite to kaolinite and that of calcite to quartz) are conserved from the soil to the aerosol if the comparison is restricted to roughly the same size fractions (clays or silt). Lafon et al. (2006) also suggested that the free- to total-iron ratio is preserved. Jeong (2008) has shown that the calcite and the K-feldspar fractions are very similar in Asian dust and the corresponding silty soil fraction. The percent of phyllosilicate is higher in the dust aerosols than in the soil, whereas the quartz and plagioclase fractions are lower.

The second transfer function describes how the dust composition is modified during transport. Our data set consists of data which have been collected at most 2 days after emission. We expect that only particles of a diameter larger than $10 \mu \mathrm{m}$ would be lost in this short time (Pye, 1987). We therefore assume that the chemical/mineralogical composition of 
our dust aerosol samples can be linked to that of the parent source regions.

To identify the pathway of air masses during transport and trace them back to an active dust source, we used back trajectory and dispersion modelling and various satellite products (e.g. Chou et al., 2008; Klaver et al., 2011). This approach does not apply to samples collected in the boundary layer during the monsoon season south of the ITCZ. In this case, the dominant flow is from the south-west: dust is present in the boundary layer only as a result of erosion by organised convection or under particularly stable conditions when high temperatures are established and the top height of the thermal turbulence in the boundary layer rises to or above the shear level, bringing dust from the free troposphere to the surface level (Flamant et al., 2009; Formenti et al., 2011b).

Even when this is the case, this approach has various caveats: first, if their horizontal velocity is high and exceeds the local threshold velocity, air masses within the boundary layer might get loaded with dust along their way before reaching the sampling point. This happens, for example, when emission is induced by large-scale frontal systems as the one of 3-7 March 2006 (Tulet et al., 2008). Secondly, ground-based sampling lasts several hours, and the direction of air masses might change in between. Finally, aircraft samples cover large areas to which different air masses from different source regions might contribute. This problem might be overcome, or at least minimised, by increasing, as much as possible, the sampling frequency to match the variability of transport. We did that by following the variability of concentrations, in time or space, with ancillary measurements at higher temporal resolution (mass concentration by the TEOM balance or the scattering coefficient by a TSI nephelometer).

In spite of this, we cannot exclude the possibility that our samples might represent larger emission areas than single "hot spots" (see, for example, Fig. 1 in Klaver et al., 2011). We do not necessary regard this as a problem, as the atmospheric dust load, both in short- and large-scale transport, is often due to a variety of sources active at the same time (Glaccum and Prospero, 1980; Reid et al., 2003; Formenti et al., 2003; Schepanski et al., 2007; Laurent et al., 2008; McConnell et al., 2008; Marticorena et al., 2010). Also, this supra-imposition, both in the vertical and in the horizontal, is what is actually seen by spaceborne sensors. The results of this paper might then be used to build a dust composition model on a scale relevant to satellites.

When doing so, we found that samples presented in this paper are representative of major African sources which, following Formenti et al. (2011) and Scheuvens et al. (2013), are indicated as PSAs (potential source areas) in Fig. 2:

- The PSA2, including arid areas in Western Sahara, Mauritania and Morocco, was sampled during the DODO and the GERBILS campaigns. With respect to

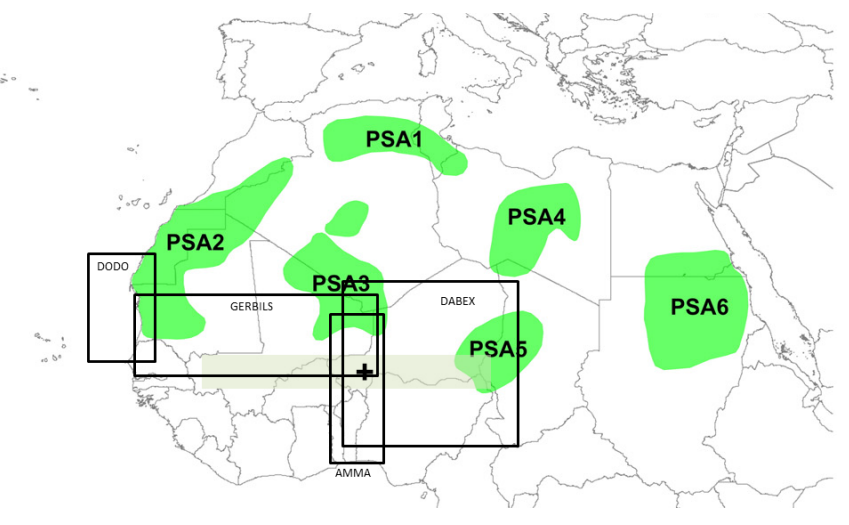

Figure 2. Geographical identification of the origin of the analysed samples superimposed on the localisation of the major potential source areas (PSA, in green) of mineral dust in western and northern Africa proposed by Formenti et al. (2011a) and Scheuvens et al. (2013) on the basis of the analysis of satellite products and the chemical/mineralogical composition of the aerosol and the parent soil. The approximate localisation of the Sahelian dust sources is also indicated by the shaded light green area. The location of the Banizoumbou ground-based site is indicated by the black cross. The operating areas of the AMMA, DABEX, DODO and GERBILS field projects are shown by black boxes. Figure reproduced from Scheuvens et al. (2013) with permission from Elsevier.

the extent of this source, the northern part is underrepresented as it was sampled on one occasion only.

- The PSA3 represents an emitting area in northern Mali and southern Algeria. This is the dominant source in terms of frequency of sampling. The air masses travelling from PSA3 often show a recirculating pathway over northern Niger. By doing so, they may at times pick up dust from the desert areas close to the Aïr massif, which is not depicted in Fig. 2, before reaching the sampling site. These occurrences, when identified, are labelled as PSA3-NN.

- The PSA4 was sampled on a few occasions during wintertime. As for PSA3, samples originating from PSA4 which involved the air masses coming into contact with the surface in northern Niger when satellite images indicated emissions have been labelled as PSA4-NN.

- A few samples also represent dust originating from the Bodélé depression (PSA5). In summertime, a mixture of Sudan and Chad sources, including Bodélé, may have been sampled (Flamant et al., 2009). Finally, a number of episodes of erosive emissions by convection in the Sahel were also sampled and characterised (referenced as Sahel). These occurred both over Mali and over Niger.

The PSA1 source is not discussed in this paper as it was not sampled during the field campaigns. 


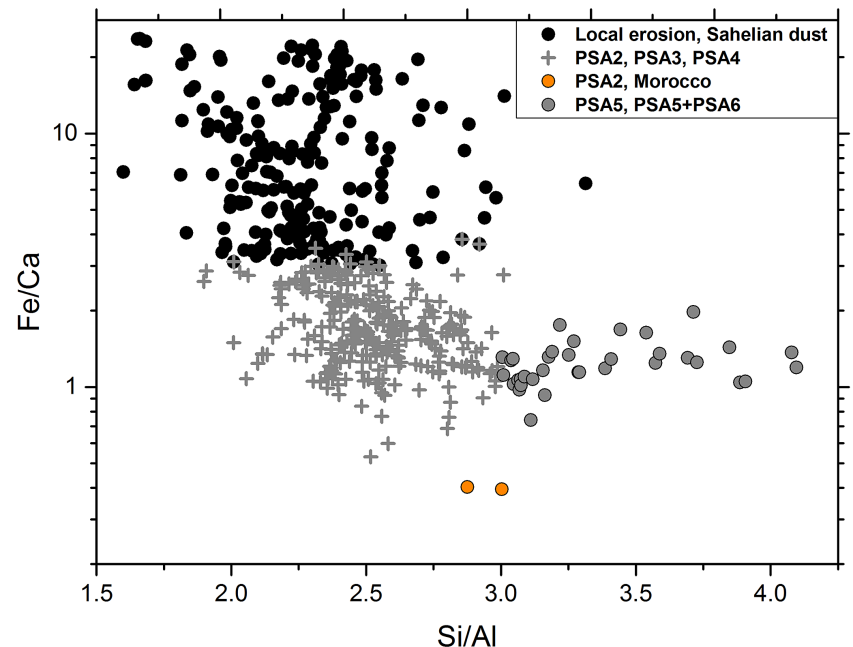

Figure 3. Scatter plot of the elemental ratio $\mathrm{Fe} / \mathrm{Ca}$ versus $\mathrm{Si} / \mathrm{Al}$ with additional information on source identification based on back trajectory, satellite and dispersion modelling.

To provide a first link between geographical origin and chemical composition, we made a scatter plot of elemental $\mathrm{Si} / \mathrm{Al}$ versus $\mathrm{Fe} / \mathrm{Ca}$, which we colour-coded according to the source region and to satellite, back trajectories and dispersion modelling information. These ratios have been shown previously to be fairly robust indicators of the origin of mineral dust on a large scale (Formenti et al. (2011a) and references therein). The result is shown in Fig. 3.

There are some clear distinctions that can be made. Data points having $\mathrm{Si} / \mathrm{Al}>3$ are unambiguously identified as samples from the Bodélé depression, i.e. PSA5. Their Fe / Ca ratio is about 1. Data points having $\mathrm{Fe} / \mathrm{Ca}>3$ are related to emission from erosive events in the Sahel. There are various sub-ranges in this group. Data having $\mathrm{Fe} / \mathrm{Ca}$ in the range of 3-5 correspond to transported dust aerosol from the Sahel, sampled 1-2 days after emission and corresponding to mixed sources, such as PSA3 + Sahel. Data having Fe $/ \mathrm{Ca}>5$ correspond to samples collected immediately or at a very early stage after emission by convective events, mostly locally at the ground-based Banizoumbou site (when the $\mathrm{Fe} / \mathrm{Ca}$ ratio exceeds 10) but occasionally from uplifted dust onboard aircraft.

Data with $\mathrm{Si} / \mathrm{Al}$ in the range of $2.5-2.9$ and $\mathrm{Fe} / \mathrm{Ca}$ in the range of 1-3 have their origins mostly at latitudes in the range of $16-27^{\circ} \mathrm{N}$, i.e. PSA3. Whereas the variability of the $\mathrm{Si} / \mathrm{Al}$ ratio is low, that of $\mathrm{Fe}$ and $\mathrm{Ca}$ can be used to make some distinctions amongst sources. $\mathrm{Fe} / \mathrm{Ca}$ higher than 1 is measured in data points from northern Mali, Mauritania, Algeria, northern Niger and Libya whereas $\mathrm{Fe} / \mathrm{Ca}<1$ is measured in dust from Western Sahara (PSA2). For this source, there are two clear outliers corresponding to samples of dust originating from Morocco and showing the lowest $\mathrm{Fe} / \mathrm{Ca}$ ratio $(\sim 0.4)$.

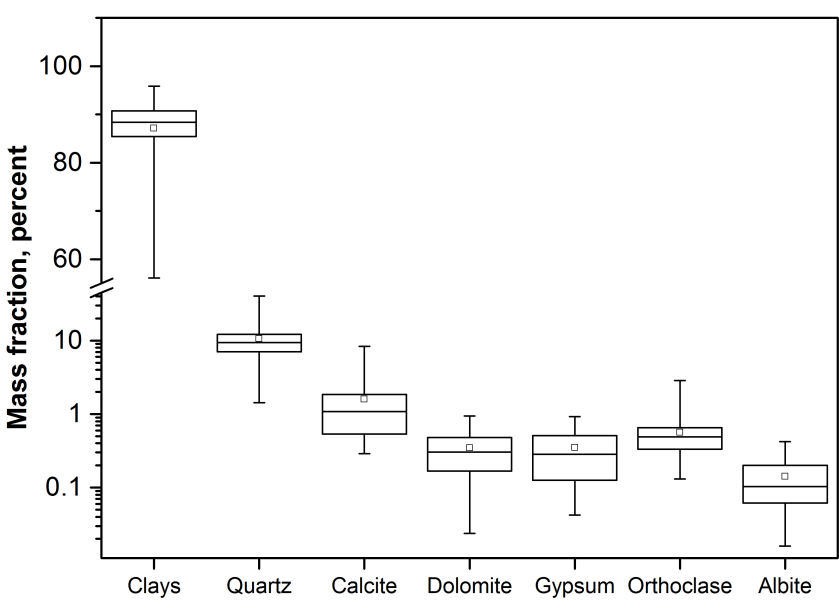

Figure 4. Range of variability of the mineral content (in percent) as obtained by XRD analysis. Boxes indicate the 25,50 and $75 \%$ percentiles. Whiskers indicate the minimum and the maximum values, whereas the open squares indicate the mean value of the distribution.

\subsection{Mineralogical composition}

The investigation of the mineral composition is based on 51 samples, 15 of which were collected onboard an aircraft. This data set represents a diversity of sources and emission conditions.

The most evident peaks, for all samples, are those of illite, kaolinite and quartz. Less evident, and not ubiquitous, are the peaks corresponding to feldspars (albite and orthoclase) and calcium-rich minerals (calcite, dolomite, gypsum). Feldspars are found in the samples from local erosion and southern Algeria, northern Niger, Mauritania and Western Sahara. This last set might also contain calcium-rich minerals. Smectite clays are detected as a large and rather weak peak at angles comprised between 4 and $7^{\circ}$. This is indicative of the fact that smectites are a family of weathered clays of different chemical composition (e.g. montmorillonite, nontronite), whose crystalline structure can be heavily modified in the environment. Smectite clays were only evident in samples originating from southern Algeria, northern Niger, Mauritania and Western Sahara.

We can obtain the mass fractions of minerals which can be detected by X-ray diffraction by using the calibration factors as described in Sect. 2.3.2 (Fig. 4).

Regardless of origin, clays and quartz account in average for $87 \%( \pm 6)$ and $10 \%( \pm 6)$ of the diffracting mass. There is only one clear outlier in an episode of intense local erosion sampled at the Banizoumbou supersite (sample SOP18 ) for which the percent clay fraction is reduced (56\%) and the quartz and feldspars fraction enhanced (41 and 3.3\%, respectively). This is consistent with the fact that, at erosion, the size distribution shows an enrichment of coarse particles 


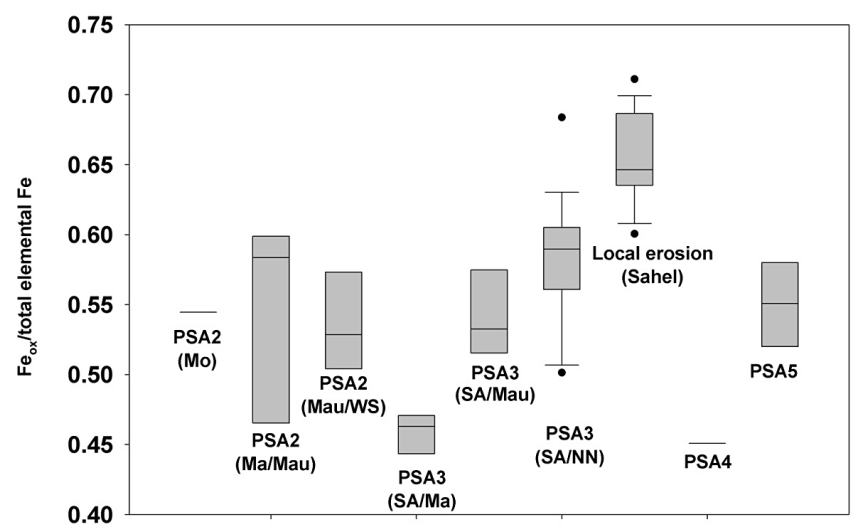

Figure 5. Variability of the iron oxide content (ratio of $\mathrm{Fe}_{\mathrm{ox}}$ to total elemental $\mathrm{Fe}$ ) according to the source region. Boxes indicate the 25 , 50 and $75 \%$ percentiles. Whiskers indicate the minimum and the maximum values, and points indicate the 5 and $95 \%$ percentiles. Data labels are as follows: Mo stands for Morocco; Ma stands for Mali; Mau stands for Mauritania; SA stands for southern Algeria; and NN stands for northern Niger.

whose composition should be closer to that of the soil silt fraction (Gillette and Walker, 1977; Chatenet et al., 1996).

The analysis of the XRD spectra also show that kaolinite and illite are very often the only clay species detected. A broad peak corresponding to smectites was detected on samples from Algeria and, at times, Bodélé, consistent with the finding of Moreno et al. (2006). No chlorite has been detected in our samples. As explained in the subsection "Calculation of the mineralogical composition" of Sect. 2.4.2, the relative proportions (by mass) of illite and kaolinite have been estimated using the origin-dependent ratios established by Caquineau et al. (2002). For the sources considered in this data set, the illite-to-kaolinite ratios could vary between 0.1 and 2.3. The central and western Saharan sources (PSA2 and PSA3) display the highest values (1.6 to 2.3) for PSA5; northern Niger and Sahel display the lowest values $(0.1$ to $0.7)$.

\subsection{Iron oxide content and speciation}

The quantification of the content of iron in oxide form $\left(\mathrm{Fe}_{\mathrm{ox}}\right)$, that is, free iron which is not in the crystal lattice of aluminosilicates, was performed for 81 samples of different origins and load (33 of these were collected onboard aircraft). On average, $\mathrm{Fe}_{\mathrm{ox}}$ accounts for $58 \pm 7 \%$ of the mass of elemental Fe. The range of variability is illustrated in Fig. 5.

The lowest values (down to $44 \%$ ) are found for samples of dust originating from the PSA4 (Chad/Egypt) area and for a set of samples collected above the PSA2 areas. The highest values (up to $71 \%$ ) are obtained for samples of dust emitted by local erosion in the Sahel, including one episode in which uplifted dust was collected onboard an aircraft after emission. Other subsets of samples, such as those of dust

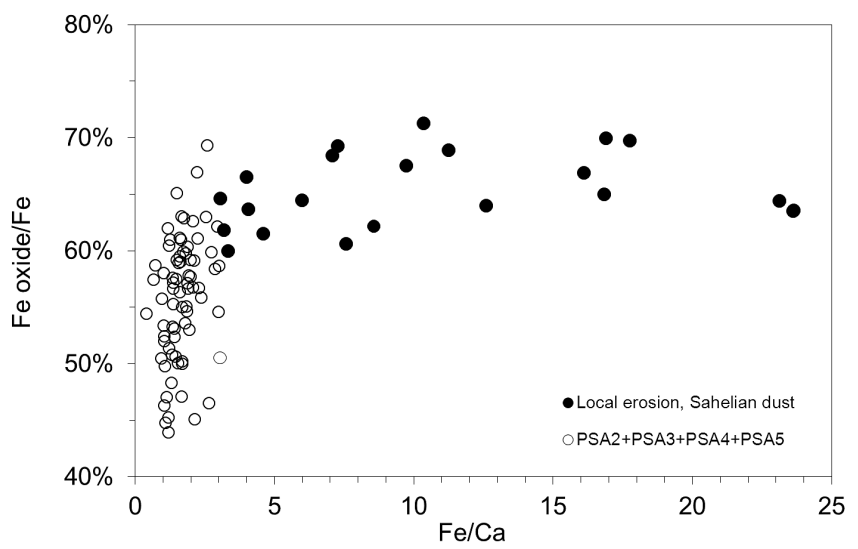

Figure 6. Dependence of the $\mathrm{Fe}_{\mathrm{ox}}$ content ( $\mathrm{Fe}_{\mathrm{ox}}$-to-Fe ratio) on the $\mathrm{Fe} / \mathrm{Ca}$ ratio for samples of different source regions identified in this study.

originated from the southern Algeria/northern Niger areas, display equally high values when, during long-range transport, dust from Algeria mixes with locally produced dust in Niger. It should also be noted that, because of the internal variability of each group, there is no statistically significant difference between the iron oxide fractions of the total iron for long-range-transported dust originating in latitudes north of $16^{\circ} \mathrm{N}$. A broad distinction between the $\mathrm{Fe}_{\mathrm{ox}}$-to-Fe ratio of Sahelian samples with respect to those of Saharan samples can be made by sorting the data points by their corresponding $\mathrm{Fe} / \mathrm{Ca}$ ratio. Mineral dust emitted from the $\mathrm{Sa}-$ hel $(\mathrm{Fe} / \mathrm{Ca}>3)$ is characterized by a mean $\mathrm{Fe}_{\text {ox }}$-to-Fe ratio value of $65 \%$ ( $\pm 5 \%$, standard deviation of the mean), whereas episodes of transport from the Sahara $(\mathrm{Fe} / \mathrm{Ca}<3)$ are characterized by a mean ratio of $56 \%( \pm 6 \%)$. No further distinction based on origin is possible in this second group of samples. This is illustrated in Fig. 6.

$\mathrm{X}$-ray absorption spectroscopy on 12 samples of differing origins indicated that goethite is, overall, the dominant species of iron oxides. Goethite accounts for 48 to $73 \%$ of the iron oxide mass, whereas hematite accounts for 27 to $52 \%$. These values do not show a clear trend with respect to the sample origin. The relative proportions of iron in the form of hematite and goethite with respect to total iron are shown in Table 2.

\subsection{Titanium oxide content}

Titanium oxides deserve attention as they are involved in photocatalytical heterogeneous reactions with various atmospheric constituents, including volatile and semi-volatile organic compounds, which are found in transport regions of mineral dust due to biomass burning emissions (Gustafsson et al., 2006).

We therefore examined our data set in order to provide estimates of the content of titanium oxides in mineral dust from various sources in western Africa. The titanium oxide 
Table 2. Mean percent values of the oxide fraction of total Fe and relative proportions of hematite and goethite to total iron oxide as obtained by XAS/XANES analysis. Standard deviations are indicated in parentheses.

\begin{tabular}{lrrr}
\hline Origin & $\begin{array}{r}\text { Oxide fraction } \\
\text { of total Fe }(\%)\end{array}$ & $\begin{array}{r}\text { Goethite fraction } \\
\text { of Fe oxide }(\%)\end{array}$ & $\begin{array}{r}\text { Hematite fraction } \\
\text { of Fe oxide }(\%)\end{array}$ \\
\hline PSA5 (Bodélé) & $43( \pm 11)$ & $65( \pm 7)$ & $35( \pm 7)$ \\
PSA3 (northern Niger) & $57( \pm 2)$ & $59( \pm 8)$ & $41( \pm 8)$ \\
PSA3 (southern Algeria) & $55(-)$ & $62(-)$ & $38(-)$ \\
Erosion, Sahel & $66( \pm 5)$ & $68( \pm 5)$ & $32( \pm 5)$ \\
\hline
\end{tabular}

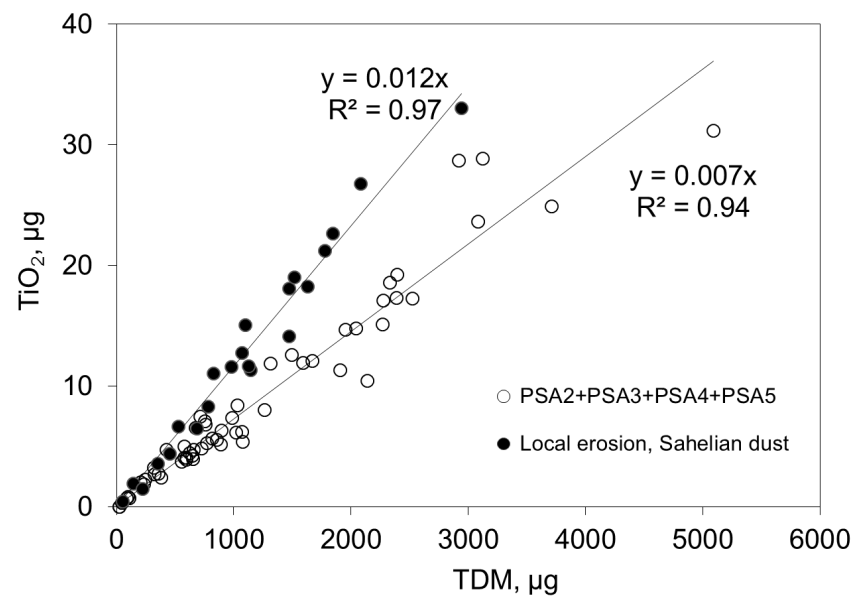

Figure 7. Scatter plot of the estimated mass of $\mathrm{TiO}_{2}$ with respect to the total dust mass (TDM). Open circles are used to display values for samples corresponding to transport of Saharan dust, whereas filled circles are for samples corresponding to local emission in the Sahel.

content has been estimated from the measured elemental $\mathrm{Ti}$ concentration (obtained by XRF), which is converted to $\mathrm{TiO}_{2}$ using the appropriate molar mass conversion factor (1.67). This should be considered as an upper-limit estimate as some of the titanium in mineral dust is present as a substitution element in aluminosilicates (Dolcater et al., 1970).

Figure 7 presents the correlation between $\mathrm{TiO}_{2}$ and the TDM. Two populations can be identified: one corresponding to samples collected in relation to erosion events and one corresponding to advection events. For both populations, the correlation is excellent $\left(R^{2}\right.$ equal to 0.97 and 0.92 , respectively) and the scatter of points is minimal. The $\mathrm{TiO}_{2}$ content is higher in erosion events from the Sahelian region (average $1.2 \%( \pm 0.1)$ of the mass) than for advection events of Saharan dust, for which $\mathrm{TiO}_{2}$ represents, on average, $0.71 \%$ $( \pm 0.01)$ of the mass.

Looking at the elemental ratios between $\mathrm{Ti}, \mathrm{Fe}$ and $\mathrm{Fe}_{\mathrm{ox}}$ provides further insights (Fig. 8). The ratio of $\mathrm{Ti}$ to $\mathrm{Fe}$ is insensitive to changes in the proportions of $\mathrm{Fe}_{\mathrm{ox}}$ to $\mathrm{Fe}$ up to $60 \%$ and then starts increasing linearly with increasing $\mathrm{Fe}_{\mathrm{ox}}-$ to-Fe ratio. This suggests that, in Sahelian dust, Ti is associated with iron oxides but that is not the case for Saharan dust.

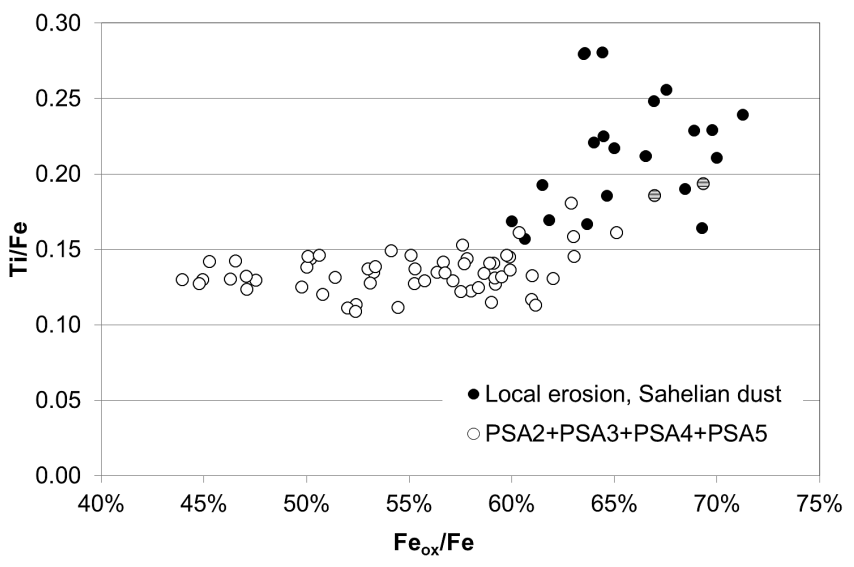

Figure 8. Scatter plot of the $\mathrm{Ti} / \mathrm{Fe}$ ratio with respect to the $\mathrm{Fe}_{\mathrm{Ox}^{-}}$ to-Fe ratio.

\subsection{Mass apportionment of the mineralogical composition}

By combining the information presented in Sects. 3.1 to 3.4, we can estimate the mineralogical composition of samples of mineral dust of local or distant origin.

The mass apportionment is shown in Table 3. Note that we provide, here, the composition of the bulk mineral dust, without explicitly taking into account the dependence on size.

There are clear similarities in the composition of the dust from the different origins, first of all in the fact that the clay fraction represents the largest fraction of the dust mass. Also note the absence of Ca-rich minerals (calcite, dolomite, gypsum) in dust originating from the Sahel compared to that originating elsewhere.

Despite the overall similarities, there is indeed a large internal variability within each source group, expressed by the standard deviation around the mean; this might be related to either the time or height after transport.

An example is provided by the composition of the four samples in the Bodélé/Sudan group: one sample was collected in the dry season, whereas the remaining three are sequenced samples collected in the wet season, a time characterised by the absence of local emission but also by a progressively increasing entrainment of dust transported from the free troposphere to the surface layer (J. L. Rajot, personal 
Table 3. Mineralogical composition (percentage by mass) according to the source region. Standard deviations are indicated in parenthesis. DL: detection limit.

\begin{tabular}{|c|c|c|c|c|c|c|c|c|c|c|c|}
\hline Source & Kaolinite & Illite & Quartz & Orthoclase & Albite & Calcite & Dolomite & Gypsum & Goethite & Hematite & $\begin{array}{r}\text { Titanium } \\
\text { oxide }\end{array}$ \\
\hline Bodélé (wintertime) & $84.1(-)$ & $8.5(-)$ & $2.9(-)$ & $0.2(-)$ & $<\mathrm{DL}$ & $0.9(-)$ & $<\mathrm{DL}$ & $0.2(-)$ & $1.6(-)$ & $1.1(-)$ & 0.7 \\
\hline Bodélé/Sudan (summertime) & $76.1(4.4)$ & $7.0(0.4)$ & $11.2(5.6)$ & $0.5(0.2)$ & $0.1(0.1)$ & $1.3(0.8)$ & $0.3(0.1)$ & $0.2(-)$ & $2.0(0.3)$ & $1.3(0.3)$ & 0.7 \\
\hline Northern Niger/Libya & $54.0(-)$ & $37.8(-)$ & $4.6(-)$ & $0.2(-)$ & $<\mathrm{DL}$ & $0.4(-)$ & $<\mathrm{DL}$ & $<\mathrm{DL}$ & $1.5(-)$ & $0.8(-)$ & 0.8 \\
\hline Northern Niger/Libya/southern Algeria & $60.5(4.7)$ & $24.0(1.9)$ & $3.6(3.1)$ & $0.2(-)$ & $<\mathrm{DL}$ & $6.3(2.9)$ & $<\mathrm{DL}$ & $<\mathrm{DL}$ & $3.1(0.2)$ & $1.6(0.1)$ & 0.8 \\
\hline Southern Algeria/Mali & $71.1(13.5)$ & $16.4(11.8)$ & $7.1(0.8)$ & $0.4(0.2)$ & $0.2(0.1)$ & $1.5(0.01)$ & $0.7(0.4)$ & $0.3(-)$ & $1.1(0.1)$ & $0.8(0.05)$ & 0.8 \\
\hline Southern Algeria/northern Niger (smectites) & $75.2(3)$ & $7.0(0.3)$ & $10.8(2.0)$ & $0.6(0.2)$ & $0.1(0.1)$ & $0.9(0.6)$ & $0.4(0.2)$ & $0.5(-)$ & $2.4(0.6)$ & $1.7(0.4)$ & 0.8 \\
\hline Southern Algeria/northern Niger (non smectites) & $78.2(2.2)$ & $7.2(0.2)$ & $6.6(0.7)$ & $0.4(0.1)$ & $0.1(0.02)$ & $3.0(3.6)$ & $0.2(0.05)$ & $0.6(0.3)$ & $2.4(1.5)$ & $1.8(1.1)$ & 0.8 \\
\hline Northern Niger & $78.3(-)$ & $7.4(-)$ & $9.7(-)$ & $0.5(-)$ & $0.1(-)$ & $<\mathrm{DL}$ & $0.3(-)$ & $0.9(-)$ & $1.4(-)$ & $0.7(-)$ & 0.8 \\
\hline Local erosion (all) & $73.0(13)$ & $7.1(1.3)$ & $14.3(13)$ & $0.8(1)$ & $0.1(0.2)$ & $<\mathrm{DL}$ & $0.1(-)$ & $0.3(0.3)$ & $2.1(0.5)$ & $1.2(0.4)$ & 1.3 \\
\hline Local erosion (quartz-rich) & $46.6(-)$ & $4.4(-)$ & $40.6(-)$ & $2.9(-)$ & $0.4(-)$ & $<\mathrm{DL}$ & $<\mathrm{DL}$ & $<\mathrm{DL}$ & $2.4(-)$ & $1.4(-)$ & 1.4 \\
\hline Local erosion (excluding quartz-rich) & $78.3(1.5)$ & $7.5(0.2)$ & $9.1(2.2)$ & $0.4(0.1)$ & $<\mathrm{DL}$ & $<\mathrm{DL}$ & $0.1(-)$ & $0.3(0.3)$ & $2.0(0.6)$ & $1.1(0.4)$ & 1.4 \\
\hline Mali/Mauritania & $29.7(-)$ & $46.3(-)$ & $17.3(-)$ & $1.3(-)$ & $0.4(-)$ & $1.0(-)$ & $0.8(-)$ & $<\mathrm{DL}$ & $1.3(-)$ & $0.7(-) \mathrm{x}$ & 1.3 \\
\hline Mali/Mauritania/Western Sahara & $30.7(3.2)$ & $54.2(6.0)$ & $8.4(1.7)$ & $0.3(0.1)$ & $0.2(0.2)$ & $1.2(0.9)$ & $0.2(0.2)$ & $0.4(-)$ & $2.0(0.5)$ & $1.3(0.3)$ & 1.3 \\
\hline
\end{tabular}

communication, 2013). These wet-season samples have a lower clay fraction and a higher quartz and feldspar content (in the range of $7-18 \%$ and $0.4-0.8$, respectively). This variability corresponds to differences in the volume size distribution, normalised to the total volume for sake of comparison (Fig. 9). As a matter of fact, the volume size distribution of the dry-season sample presents a large coarse mode peaking around $4-5 \mu \mathrm{m}$, whereas the wet-season samples have a bimodal volume size distribution with an additional mode centred at $8 \mu \mathrm{m}$. Within this group, the sample having the largest quartz fraction is also the one displaying the larger fraction of particles above $10 \mu \mathrm{m}$.

A second example of the links between time after emission, size distribution and composition is given in Fig. 10. This shows the normalised particle size distributions (by volume) for one case of Sahelian dust by local erosion (sample SOP1-8), two samples representing the background dust composition in the absence of local erosion (SOP1-15 and SOP1-60) and one case representing the composition of Sahelian dust advected at the sampling site after having been emitted by local erosion nearby (SOP1-17). There are clear differences between these cases: sample SOP1-8 has a mode at $8 \mu \mathrm{m}$ and the largest coarse-particle fraction; Samples SOP1-15 and SOP1-60 have a bimodal size distribution with modal diameters at 3-4 and $8 \mu \mathrm{m}$; finally, only the mode at 3$4 \mu \mathrm{m}$ remains for sample SOP1-17. As for the case presented in Fig. 9, it is evident from Fig. 10 that the coarse mode at $8 \mu \mathrm{m}$ bears most of the quartz and feldspar mass fractions and that the dynamic evolution of this mode controls the content of quartz and feldspar in dust. The comparison of Figs. 9 and 10 also suggests that, once the mode at $8 \mu \mathrm{m}$ is deposited, differences in the mineralogical composition of mineral dust will be more independent of the size dynamics and reflect better the differences in the mineralogy of the parent soil.

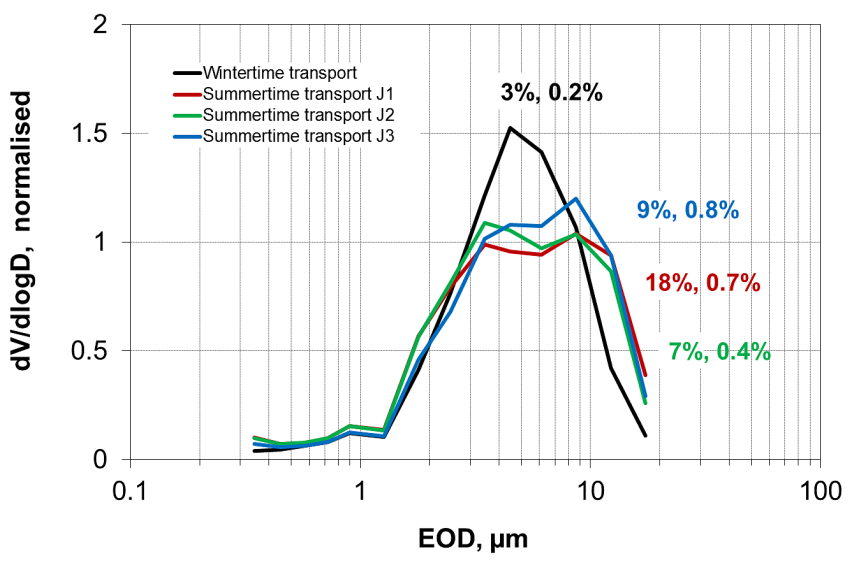

Figure 9. Normalised volume size distribution $\mathrm{d} V / \mathrm{d} \log$ (equivalent optical diameter, EOD) at Banizoumbou during 3 consecutive days in summer (labelled J1 (red line), J2 (green line) and J3 (blue line)) and one day in winter (black line) for samples representing dust transported from the Bodélé source region. Data are reported as a function of the EOD as obtained by optical counter measurements without any corrections for the sample refractive index.

\section{Discussion}

\subsection{Comparison with other data sets}

All comprehensive papers relating to the composition of mineral dust state that the comparison of compositional data from different data sets depends critically on the experimental conditions, in particular the duration and location of sampling (integration time, near-source location) (Formenti et al., 2011a; Scheuvens et al., 2013). These considerations are particularly relevant to aircraft sampling, where the difficulty in controlling the size cut-off of samplers generally does not favour the coarse-particle fraction in an often nonquantified way (Formenti et al., 2011a). Furthermore, as the aircraft is moving during sampling, a 20 min aircraft sample will represent a distance of the order of $120 \mathrm{~km}$, which might 


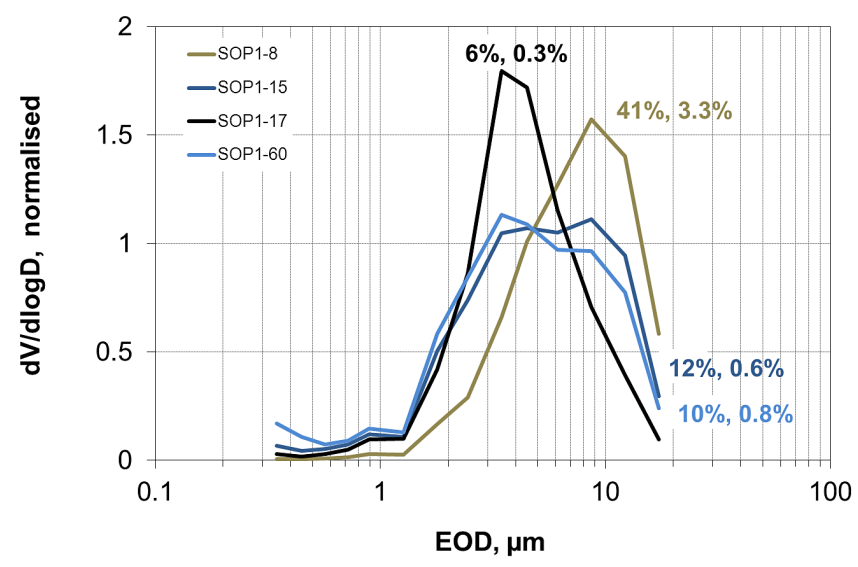

Figure 10. Normalised volume size distribution $\mathrm{d} V / \mathrm{d} l o g$ (EOD) for samples representing emitted dust in the Sahel during episodes of local erosions. The explanation of the sample ID is given in the text.

combine the contribution of various sources (Klaver et al., 2011).

As a consequence, the integration and the comparison of different data sets of the composition of mineral dust is not a straightforward exercise.

Overall, our results indicate the dominance of clays in the dust composition when only the aerosol fraction is measured. In this respect, they are in accordance with previously published papers for dust collected in Africa (Kandler et al., 2009) or after long-range transport (Delany et al., 1967; Kiefert et al., 1996; Glaccum and Prospero, 1980; Caquineau et al., 2002). These measurements, however, tend to indicate that the clay fraction accounts for $\sim 60-70 \%$ of the dust weight, whereas our measurements suggest higher values (80-90\%). It should be remembered that the determination of the mineralogical composition will depend on the crystallography of the standard minerals used for calibration, and on the normalisation to the total dust mass. In our work the percentage of clays in dust depends directly on the normalisation factor, regarding which we have an uncertainty of the order of $17 \%$ as we estimate clays from the difference between the total dust mass and the calibrated mass of non-clay compounds. As an example, Glaccum and Prospero (1980), using standard clays minerals for calibration, estimate that the crystalline mass represented 70 to $110 \%$ of the weighed mass. These values reflect, at least partially, the uncertainty regarding the clay fraction.

Nonetheless, in some cases differences might be due to the sampled aerosol size distribution. As a matter of fact, the lowest detected percentage of clays corresponds to sample SOP1-8, collected during an intense episode of local erosion. In this case, clays account for around $50 \%$ of the measured mass, in accordance with measurements by Caquineau et al. $(1997,2002)$ in similar conditions.
The influence of size on composition is also clear, for example, by looking at the data published by Kandler et al. (2009), who documented the dust composition in a dust storm (total suspended particulate concentrations higher than $300000 \mu \mathrm{g} \mathrm{m}^{-3}$ ) and in low-dust periods (total suspended particulate concentrations around $100 \mu \mathrm{g} \mathrm{m}^{-3}$ ) in Morocco. Quartz accounts for as much as $\sim 65 \%$ in dust storm conditions, suggesting that soil grains, and not only aerosols, were sampled. Conversely, low-dust conditions are characterised by only about $20 \%$ of quartz. These authors showed that, for locally emitted dust, illite is dominant over kaolinite (up to 30 and $5 \%$ by volume, respectively). These authors also detected clay in the form of chlorite (less than $10 \%$ by weight) and calcite (up to $15 \%$ ).

Few authors have published data on the iron oxide content. Lafon et al. (2004) evaluated the free-to-total iron content in samples collected at the Banizoumbou ground-based site and found mean values of $0.44( \pm 0.11)$ and $0.65( \pm 0.04)$ for dust transported in the Harmattan flow (from the Sahara) and dust emitted locally by convective erosion. Lazaro et al. (2008) found slightly lower values than ours ranging from 0.26 to 0.63 but only exceeding 0.56 on three occasions when back trajectories indicated transport from the Sahel or a mixture of dust originating from the Sahara and the Sahel. Our values are higher than those of these authors. Nonetheless, the back trajectories presented in the paper seem to indicate that the Saharan dust originated from higher latitudes than our samples - and mostly from Tunisia and Algeria. It will be interesting in the future to sample those source areas to confirm these rather low values.

Finally, our results on the iron oxide speciation are consistent with findings of different authors using XANES speciation (Wilke et al., 2001; Ohta et al., 2006; Prietzel et al., 2007; Majestic et al., 2007) and visible spectroscopy (Arimoto et al., 2002), indicating that $\mathrm{Fe}(\mathrm{III})$ is the dominant redox form of iron oxides and that goethite is the predominant form of iron oxide over hematite.

\subsection{Atmospheric implications}

The results showed in this paper suggest that, when restricted to the mass fraction below $20 \mu \mathrm{m}$, the dust composition in western Africa may apparently be simplified to a few minerals, clays, quartz, calcite, iron and titanium oxides. Feldspars and other calcium-containing minerals such as dolomite and gypsum are very minor components, close to detection limits. The geographical distribution of the dust composition is relatively unimportant in terms of mass fractions, in particular in comparison to the importance of the size distribution, whose variability with time seems to be able to explain some differences observed between samples from the same source region at different times after emission. Nonetheless, it is important to evaluate whether differences in composition on the regional scale, even when minor, might give rise to differences in the impacts of mineral dust. 
Table 4. Complex refractive indices of individual minerals used in this study. The spectral domains are indicated.

\begin{tabular}{llr}
\hline Mineral & Reference & Spectral domain $(\mu \mathrm{m})$ \\
\hline Illite & Egan and Hilgeman (1979) & $0.185-2.6$ \\
& Querry (1987) & $2.5-200$ \\
& Glotch et al. (2007) & $5-100$ \\
\hline Kaolinite & Egan et Hilgeman (1979) & $0.185-2.6$ \\
& Roush et al. (1991) & $5-25$ \\
& Glotch et al. (2007) & $5-100$ \\
\hline Calcite & Querry et al. (1978) & $0.2-25$ \\
& Long et al. (1993) & $2.5-300$ \\
\hline Dolomite & Barthelmy (2007) & $0.185-2.5$ \\
& Querry (1987) & $2.5-40$ \\
\hline Albite & Barthelmy (2007) & $0.185-2.5$ \\
\hline Orthoclase & Barthelmy (2007) & $0.185-2.5$ \\
\hline Gypsum & Barthelmy (2007) & $0.185-2.5$ \\
& Long et al. (1993) & $2.5-300$ \\
\hline Goethite & Bedidi and Cervelle (1993) & $0.46-0.7$ \\
& Glotch and Rossman (2009) & $8.3-50$ \\
\hline Hematite & Bedidi and Cervelle (1993) & $0.4-0.7$ \\
& Marra et al. (2005) & $6.5-50$ \\
& Longtin et al. (1988)* & $0.2-300$ \\
\hline Quartz & Longtin et al. (1988)* & $5-37$ \\
& Peterson and Weinman (1969) & $0.2-2$ \\
& Spitzer and Kleinman (1961) & 5 (195) \\
\hline
\end{tabular}

* Longtin et al. (1988) have compiled values of complex refractive indices for hematite and quartz based on different sources.

To do so, we explore the influence of dust composition on the spectral complex refractive index $\tilde{\mathrm{n}}$ and the fraction iron solubility.

\subsubsection{Implications for optical properties}

As a mean of evaluating the effect of the variability of composition on dust optical properties, the volume-average refractive index has been calculated as

$\tilde{n}=\sum_{j} f_{j} \times \tilde{n}_{j}$,

where $f_{j}$ is the volume fraction of each individual mineral in the dust sample (as reported in Table 3) and $\tilde{\mathrm{n}}_{i}$ is its complex refractive index. Equation (4) assumes that minerals in dust are internally mixed. In reality, minerals are present in dust as external mixtures, with the exception of iron oxides, which may be found as inclusions in clays (Sokolik and Toon, 1999). However, the internal mixing hypothesis is frequently used in experiments and climate models (e.g. Balkanski et al., 2007; Kandler et al., 2009; McConnell et al., 2010; Hansell et al., 2011).

Values of the complex refractive index $\tilde{\mathbf{n}}_{j}$ of the individual minerals detected in our samples are listed in Table 4. We have restricted the calculations to two spectral domains: the near UV-visible between 370 and $700 \mathrm{~nm}$ and the thermal IR from 8 to $15 \mu \mathrm{m}$, where values for all individual minerals are available.

Results are presented in Fig. 11, where they are compared to the values of the "desert" dust aerosol model in the OPAC (Optical Properties of Aerosols and Clouds) database (Hess et al., 1998), often used in satellite retrieval algorithms in the thermal infrared (see Table 1 in Klüser et al., 2012) but also in radiative transfer calculations (Highwood et al., 2003; Haywood et al., 2005). The "desert" model in the OPAC database represents the properties of mineral dust in the source region, with the dust considered to be a mixture of quartz and clays in different size fractions.

We restrict Fig. 11 to the visible and infrared imaginary parts of the complex refractive index $\tilde{\mathrm{n}}_{i}$. In the visible, the imaginary part of the complex refractive index is relatively constant with wavelength. Mean values are of the order of 0.003 , with standard deviation of the order of 0.001 , with the exception of data from the PSA4 source, which average at 0.006 and present a standard deviation of 0.003 . It is difficult to judge this variability as it is induced by one sample only, representing an outstanding iron oxide fraction. In the infrared, the imaginary part shows a band-type structure relating to the major absorption bands of clays and quartz, mostly found in the atmospheric window between 8 and $11 \mu \mathrm{m}$. There is very little sample-to-sample variability in the position of the bands or in the relative proportions of the band peaks, with the exception of the Sahelian dust samples, which present a larger standard deviation due to the enhancement of the band at $9.2 \mu \mathrm{m}$ corresponding to the outstanding quartz fraction of sample SOP1-8. There is very little difference in the spectra of sources PSA3, PSA4 and, to a lesser extent, PSA5, which have the highest absorption values at $9.6 \mu \mathrm{m}$. However, the spectral dependence for dust from source PSA2 is different (peak at $9.2 \mu \mathrm{m}$ more pronounced than that at $9.6 \mu \mathrm{m})$.

The composition-based refractive indices calculated in this study are very different to those of the OPAC database. Below $0.6 \mu \mathrm{m}$, the volume-averaged values are lower than the OPAC values, with the exception of values for the PSA4 samples, due to their larger standard deviation. Above $0.6 \mu \mathrm{m}$, the two data sets converge. The spectral dependence is also inconsistent and reflects the reduced spectral variability of the values for iron oxides (both hematite and goethite) in Bédidi and Cervelle (1993) with respect to other commonly used databases, such as that of Shettle and Fenn (1979) for hematite on which OPAC is based.

The calculated volume-average infrared values in the absorption band between 8 and $10 \mu \mathrm{m}$ are two times higher than in the OPAC database. The main reason for this is the volume-mixing rule, which enhances absorption. Additionally, for single-mineral species, various authors (Hudson et al., 2008a, b; Mogili et al., 2007, 2008) found strong differences in peak positions and spectral shape between extinction 

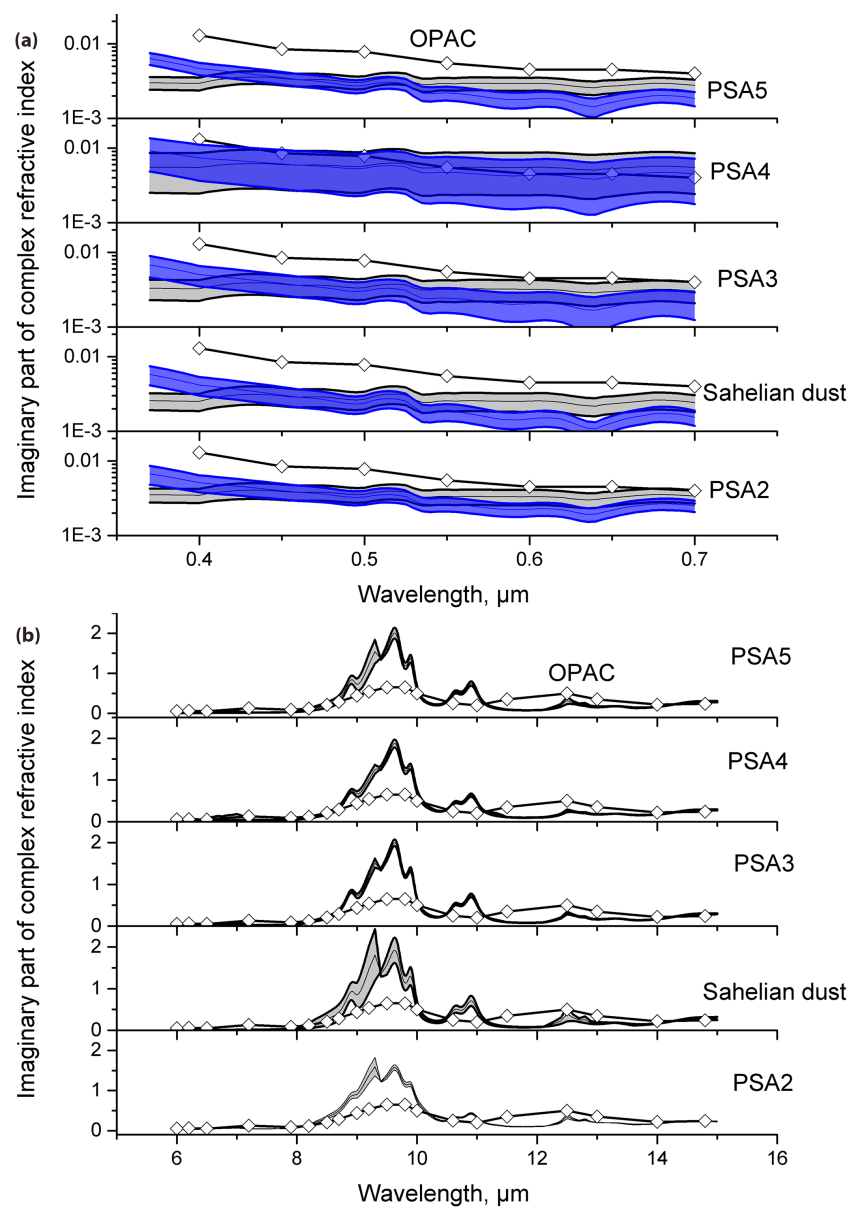

Figure 11. Imaginary part of the complex refractive index calculated from the mineralogical composition of dust originating from sources PSA5, PSA4, PSA3, local erosion in the Sahel, and PSA2 (from top to bottom). Panel (a) represents the real part in the $0.3-0.7 \mu \mathrm{m}$, calculated assuming the refractive index from Table 3 . Grey-shaded curves represent results obtained when using the data from Bedidi and Cervelle (1993) for hematite, whereas blue-shaded areas correspond to values from Shettle and Fenn (1979). Panel (b) represents the imaginary part of the complex refractive index calculated in the $6-16 \mu \mathrm{m}$ spectral domain. The black line with white diamonds represents data from the OPAC database (Hess et al., 1998).

spectra measured by Fourier transform infrared spectrometry and those calculated from published optical constants. All these studies show residual differences suggesting that optical constants might vary depending on whether they had been determined using powders or bulk samples, on the degree of water association of minerals and on their chemical form (substitutions, impurities). As this variability might be even larger when looking at actual dust samples, the comparison clearly suggests that new measurements of IR extinction spectra on real dust samples representative of the mineralogical composition of the different source areas are required.

\subsubsection{Implications for Fe fractional solubility}

The solubility of dust iron is a function of iron speciation, i.e. oxidation states, bonding environments and mineralogy (Journet et al., 2008; Schroth et al., 2009). Thus, due to higher solubility of iron trapped in the crystal lattice of aluminosilicates and the large abundance of clay minerals, Journet et al. (2008) suggested that the use of hematite as a single source of DFe in biogeochemical models might cause an underestimation of the DFe supply to the ocean. On this assumption, Paris et al. (2011) showed that the iron fractional solubility in mineral dust can be estimated as the sum of the Fe solubility of various minerals compounding iron in the dust matrix. We propose to apply this calculation to this data set to estimate the solubility of dust in the source region. For this purpose, we use the iron solubility from minerals measured by Paris et al. (2011) at $\mathrm{pH}=4.7$, the typical $\mathrm{pH}$ of African rainwaters (Desboeufs et al., 2010), i.e. SFe equal to $0.17 \%$ for illite and $0.006 \%$ for free iron from goethite and hematite. Paris et al. (2011) made the approximation that all the iron associated with clay is present as illite. Journet et al. (2008) emphasized that even the iron in impurities in kaolinite or feldspars matrices present a high solubility. Our measurements show the predominance of kaolinite in comparison to illite, so we consider also the dissolution of Fe from kaolinite due to the large proportion of this mineral in the studied samples. We use SFe equalling $0.63 \%$ for kaolinite (P. Paris, personal communication, 2013). The percent quantity of feldspar being usually inferior to $1 \%$ in the samples, we neglect the iron associated with these minerals. Smectites, such as montmorillonite, are also minerals with a high content of iron with a higher solubility (Journet et al., 2008). However, due to the difficulties in quantifying the smectite fraction, this other source of structural $\mathrm{Fe}$ is not well constrained. Moreover, Shi et al. (2011) mention the presence of highly soluble nanoparticles of ferrihydrite or poorly crystallised iron in the fine fraction of soils. However, the quantification of this iron phase is obtained by sequential extraction and is difficult to apply on field samples due to the low mass. Therefore, we are not able to consider this species in our calculation.

Among the samples present in our database, the mineralogical composition including goethite, hematite, illite and kaolinite is evaluated for 27 samples, enabling us to calculate the iron fractional solubility (Table 3 ). In this case, the iron content in illite is assumed to be equal to $4.0 \pm 0.9 \%$, which corresponds to the mean stoichiometric value of two types of illites (Fithian, Illinois, and Rochester, Minnesota, as shown in Journet et al., 2008). The iron content in illite can vary from 0.8 to $8.4 \%$ (Murad and Wagner, 1994); this large range is due to the fact that $\mathrm{Fe}$ is present as a substitution of $\mathrm{Al}$ or $\mathrm{K}$ in the sheet-like structure of illite, depending on the environmental conditions that the clay has experienced in the soil fraction (weathering, etc.). In goethite and hematite, we estimated the iron content based on the analysis of Journet 


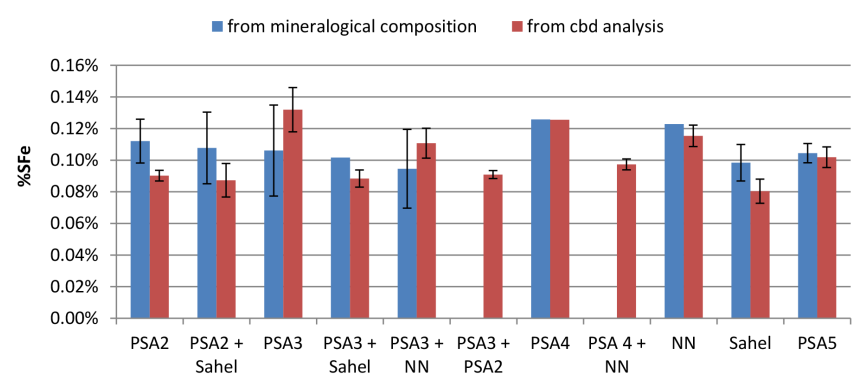

Figure 12. Iron solubility calculated from the mineralogical composition and from CBD analysis as a function of emission source. Error bars indicate standard deviation. When error bar is not presented, the data are only for one sample.

et al. (2008) and Paris et al. (2011) as 62.9 and $57.5 \%$ for goethite and hematite, respectively. For kaolinite, Mestdagh et al. (1980) showed that the iron content is related to the crystallinity of the mineral and ranges from 0.02 to $0.81 \%$ with an average of $0.4 \% \pm 0.2 \%$, which is used for our calculation.

In order to gain a wider view of the variability of iron solubility as a function of emission source, we can also calculate iron solubility from the partitioning between structural and free iron as obtained by the CBD extraction analysis (Table 2). This is doable for 85 samples, among which the 27 samples for which the mineralogical composition is estimated. In this case, we consider the structural iron $\left(\% \mathrm{Fe}_{\text {structural }}\right)$ to be associated with illite $\left(\% \mathrm{Fe}_{\text {illite }}\right)$ and kaolinite $\left(\% \mathrm{Fe}_{\text {kaolinite }}\right)$ in the proportion of the illite-tokaolinite ratio corresponding to the origin of the samples (see Sect. 3.2), such that

$\% \mathrm{Fe}_{\text {kaolinite }}-\frac{\% \mathrm{Fe}_{\text {structural }}}{\left(1+10 \times \frac{\mathrm{I}}{\mathrm{K}}\right)}$

and

$\% \mathrm{Fe}_{\text {illite }}-\% \mathrm{Fe}_{\text {structural }}-\% \mathrm{Fe}_{\text {kaolinite }}$,

with 10 representing the illite-to-kaolinite iron content ratio $(4.0 \% / 0.4 \%)$. Results are summarised in Fig. 12.

The mean value of iron fractional solubility is $0.10 \%$ $( \pm 0.02 \%)$, whatever the methods of calculation, i.e. mineralogical composition or CBD extraction analysis. There is little variability in iron solubility as a function of the source; nonetheless, this is the direct opposite of the iron oxide content, i.e. the lowest values $(0.08 \% \pm 0.01 \%)$ obtained for samples of Sahelian dust with the highest iron oxide content. Inversely, the samples with the highest solubility $(0.13 \% \pm 0.01 \%)$ issued from PSA3, i.e. southern Algeria/Mali, present a low percentage of free iron (49\%). Data show that 54 to $87 \%$ of soluble iron is structural iron associated with illite, meaning that this mineral is the major provider of soluble iron. The determining factor for this parameter is the quantification of illite and, hence, the hypothe- sis made on the illite-to-kaolinite ratio as a function of emission source, which is estimated from Caquineau et al. (2002). Thus, the regional variability in iron solubility obtained here is mainly associated with this ratio, which should be better constrained. A rapid calculation for the PSA3 samples, the richest in structural iron, shows that iron solubility is divided by a factor of 2 when I/ $\mathrm{K}$ varies from 0.1 to 2.3 , the extreme values observed by Caquineau et al. (2002). This means that the solubility between the various emission sources varies, at best, by a factor of 2 . Another source of error could be the estimation of iron oxide, which is affected by errors of $30 \%$. Sample-to-sample comparison shows that there is a rather good correspondence between the two methods of calculation (within 15\%). However, the calculation based on mineralogy yields values lower by a factor of 1.5 for the samples from PSA3 alone or for samples originating from a mixture of sources, meaning an underestimation of structural iron in comparison to the direct measurements by CBD analyses. Smectites are identified for several samples of this source; we, therefore, underestimate the calculated solubility for the samples where these minerals are present.

The mean fractional iron solubility obtained by calculation is consistent with, though rather inferior to, the observations obtained for transported Saharan dust over the Atlantic, which ranges from 0.12 to $4.1 \%$ (Sarthou et al., 2003; Baker et al., 2006; Sholkovitz et al., 2012). However, our calculations are exclusively based on mineralogical parameters, since our samples have been collected at most 2 days after emission and do not integrate the various chemical and physical processes increasing dust solubility during long-range transport, such as cloud processes (Desboeufs et al., 2001); photochemical processes (Hand et al., 2004) or organic complexation (Paris et al., 2013). Thus, the range of calculated values could be representative of iron solubility for the various sources of African dust before transport. Moreover, the limited regional variability estimated here in comparison to the variability of measurements over the Atlantic Ocean shows that the emission source of dust is less critical when estimating the fractional iron solubility of dust than the process after transport. Nevertheless, new direct measurements of the iron fractional solubility for sources of dust in western Africa are necessary to validate these conclusions.

\section{Final remarks, conclusions and perspectives}

In this paper we have presented an insight into the mineralogical composition of mineral dust from western Africa from the synthesis of the airborne and ground-based observations of field campaigns conducted between 2006 and 2007. These observations have been made at emission or within 2 days of transport into the atmosphere. The strength of this synthesis resides in the fact that the observations were made in a consistent way from the methodological point of view (both for sample collection and analysis) and that they span a large 
geographical region covering some of the major African dust sources.

The composition data presented in this paper are being made public as part of a data set called DUST-MAP, to date still in its trial version. Meanwhile, data are available upon request. The prospective evolution of this data set will be the inclusion of data from other field campaigns, both close to source regions and at some distance. Amongst these are the Fennec and the SAMUM (Saharan Mineral Dust Experiment) field campaigns (Heintzenberg et al., 2009; Ansmann et al., 2011; Washington et al., 2012), which were conducted at downwind sources in Algeria and Morocco and were relevant to large-scale transport (Caquineau et al., 2002). This will require a close-up examination of experimental protocols and a careful evaluation of their influence on the results.

The presentation of this work deserves some final considerations and opens various perspectives.

The bulk mineralogical composition of dust in western Africa can be described by a simple model where kaolinite and illite account for $80 \%$ or above of the mass, and quartz, iron and titanium oxides for the remaining $20 \%$. Calcite is a distinctive element of Saharan sources, for which it ranges between 0.3 and $8.4 \%$ of dust mass. For the remaining minerals, the variability is due to source type (e.g. the proportions of illite and kaolinite as evidenced by Caquineau et al., 2002) or to differences in the size distribution, particularly the increase of the quartz fraction corresponding to a coarse mode centred around $8 \mu \mathrm{m}$ in diameter. To the best of our knowledge, we are the first to provide a large data set of titanium oxide data, which can be relevant to atmospheric photochemistry (Ndour et al., 2008). We estimate that Sahelian dust is composed of $2 \%$ (by mass) of titanium oxides, that is, double the mass fraction of dust from sources in the PSA2, PSA3, PSA4 and PSA5 areas, with very little sample-to-sample variability. Iron oxides, also important for atmospheric chemistry processes and radiation, display higher values in Sahelian than in Saharan dust.

The discussion of the regional variability of the mineralogical composition is based on our ability to detect source areas based on satellite remote sensing or on soil property maps (e.g. Claquin et al., 1999; Schepanski et al., 2007; Laurent et al., 2008; Ginoux et al., 2012; Nickovic et al., 2013; Journet et al., 2014) and to attribute the provenance of an air mass to it via back-trajectory calculations (e.g. Klaver et al., 2011). Beside the uncertainties inherent in the detection of sources, there are two additional factors of ambiguity in source attribution: first, air masses, especially during wintertime, mostly travel in the boundary layer and might uplift dust aerosols at various times before reaching the sampling site; secondly, aircraft samples might combine transport from various sources active at the same time due to the fact that an aircraft moves during sampling and that sample collection lasts at least $20 \mathrm{~min}$, which corresponds to about $120 \mathrm{~km}$ at typical aircraft cruise speed (see Fig. 1 in Chou et al. (2008) and Fig. 1 in Klaver et al. (2011)). It is there- fore clear that some fine features of the mineralogy specific to individual sources might be lost. Nevertheless, our data represent the composition of the regional dust load well as it results from the natural mixing occurring during transport. They are also of comparable spatial resolution to those of various state-of-the-art global and regional circulation models including dust mineralogy models (Balkanski et al., 2007; Hoose et al., 2008; Huneeus et al., 2011). Henceforth, the composition data presented in this paper may serve to evaluate the regional and global model estimates of the dust mineralogical composition in the western African atmosphere and to calculate dust properties relevant to their direct, indirect and biogeochemical impacts. Claquin et al. (1999) have discussed some comparisons between the mineralogy of dust atmospheric data and that of the soil fraction predicted by a surface mineralogy table constructed from maps of the arid soil mineralogy (updates of this table have been recently published by Nickovic et al. (2012) and Journet et al. (2014)). To do so, these authors have calculated weight ratios between some minerals (calcite, feldspar and hematite, where hematite is meant to represent the sum of the content of goethite and hematite) with respect to quartz. Our data are consistent with the Claquin et al. (1999) data set regarding the variability of the calcite-to-quartz ratio but display higher and lower ratios for hematite and feldspar, respectively. Our ratio of hematite-to-quartz ranges between 0.03 and 1 (0.09 and 3 when the sum of goethite and hematite is considered) instead of $0.009-0.09$, whereas our ratio feldspar-to-quartz is in the range of 0.03-0.11 instead of that of 0.2-2 in Claquin et al. (1999). These differences illustrate the fact that our data are closer to representing the clay soil fraction, whereas the data of Claquin et al. (1999) best represent the silt fraction, richer in quartz particles. When limited to sample SOP1-8 (the local erosion sample enriched in quartz and with a particle fraction larger than $20 \mu \mathrm{m})$, ratios are 0.09 for hematiteto-quartz (0.03 if hematite only is considered) and 0.08 for feldspar-to-quartz; these are the ranges expressed by Claquin et al. (1999).

Finally, we have provided the estimate of parameters relevant to the direct impact of mineral dust on radiation and on ocean productivity: the complex refractive index $\tilde{\mathrm{n}}$ and the iron fractional solubility SFe.

Assuming internal mixing, we have shown that the complex index of refraction based on mineralogy has some variability, mostly related to the separation of illite and kaolinite and to the quartz fraction higher than $40 \%$ of the dust volume. The spectral behaviour of the estimated complex index of refraction is quite different from the OPAC database. The OPAC approach overestimates absorption in the visible. On the other hand, a very recent study presents values of the complex refractive index in the shortwave based on a global mineralogy soil map (Smith and Grainger, 2014). At $550 \mathrm{~nm}$, these authors predict a real part of the complex refractive index around 1.56, that is, higher than ours which ranges between 1.45 and 1.51 . Their imaginary part averages 
at $6.2 \times 10^{-4}$, that is, almost an order of magnitude lower than our predicted values (average $3 \times 10^{-3}$ ). This is the consequence of the fact that optical properties estimated from the soil fraction will reflect more closely the optical properties of quartz, which is enriched in the soil fraction with respect to the aerosol fraction due to the size fractionation at emission. An additional confirmation is given by the fact that, in our data, the highest value of the real part of the complex refractive index is obtained for sample SOP1-8, representing the Sahelian erosion case with the highest quartz fraction $(41 \%$ by weight), whereas the highest values of the imaginary part are obtained for samples representing long-range transport from Libya through northern Niger and having a low or even the lowest quartz percentage by weight (1.5-6\%) but having the highest calcite fraction (4-8\% by weight). As a matter of fact, quartz is transparent in the visible, whereas calcite and clays are absorbing. These considerations lead to the conclusion that not only soil mineralogy but also the transfer function between the soil and the aerosol fractions must be implemented in models estimating the dust optical properties.

In the long-wave spectrum, our calculations suggest higher absorption than the OPAC model in the atmospheric window. The 10-12 $\mu \mathrm{m}$ band, which is sensitive to differences in the mineralogical composition amongst sources, is relevant to the retrieval of various spaceborne sensors, including IASI, AIRS and MODIS (De Souza Machado et al., 2006; Hudson et al., 2008a; Klüser et al., 2011; Laskina et al., 2012). Some of the discrepancies between our values and the OPAC database are, at least partially, due to differences in the optical constants of the individual minerals. Dedicated in situ measurements of the optical constants of the dust samples would allow us to confirm this hypothesis.

Nonetheless, a limitation of this study, impacting our estimate of the complex refractive index, is the quantification of smectite-type clays. For the purposes of the present study, we have chosen to ignore the contribution of smectites, which were detected only in a few samples and which we consider as a trace component of the aerosol. Also, smectites are dominant in the $0.2 \mu \mathrm{m}$ size fraction, which is poor in mineral dust in our samples (Klaver, 2012).

In the visible, Egan and Hilgeman (1979) indicated that two different montmorillonite types (one from Wyoming and one from Mississippi) have refractive indices very similar, to those of either kaolinite or illite, both in spectral dependence and magnitude. However, below $500 \mathrm{~nm}$ the imaginary part of the complex refractive index of the montmorillonite from Mississippi is higher by a factor of 2 than that of illite, reaching 0.004 between 200 and $360 \mathrm{~nm}$. In the infrared, various authors (Toon et al., 1976; Glotch et al., 2007; Hudson et al., 2008) have shown that montmorillonite has similar optical properties to those of illite, albeit displaying a higher intensity of extinction around $9.5 \mu \mathrm{m}$ in the $\mathrm{Si}-\mathrm{O}$ stretching band. Köster et al. (1999) examined five types of nontronites and Fe-rich smectites and found that the position and the intensity of this band vary depending on tetrahedral Fe(III) content. Also, the speciation of clays, in particular that of montmorillonite, has implications for the cloud and ice nucleation properties of mineral dust and the estimate of iron fractional solubility (Hoose et al., 2008; Journet et al., 2008). Ultimately, these facts depend on the compositional heterogeneity in Al-rich smectite in the natural soils and sediments (Christidis and Dunham 1993; Christidis, 2006), due to various processes, including weathering and/or hydrothermal alteration of basic rocks (Köster et al., 1999) but also due to reduction reactions of structural Fe by microorganisms (Pentrakova et al., 2013). This makes the quantification extremely dependent on the environmental conditions. Similar considerations will hold for chlorite-type clays, which were not detected in our samples but which might be present in dust from northern African deserts, such as in Morocco and Tunisia (Paquet et al., 1984; Kandler et al., 2009). It should be noted that, to date, no measurements of the complex refractive index of chlorites are available in the shortwave. In the long wave, chlorite has significantly different optical properties than illite and kaolinite, in particular concerning their major absorption bands, which are located at $9.6 \mu \mathrm{m}$ for illite and kaolinite and at $10.2 \mu \mathrm{m}$ for chlorite (Egan and Hilgeman, 1979; Mooney and Knacke, 1985). Should chlorite be detected in the samples, its lack of quantification will be treated as an additional source of error to be evaluated.

Regarding the iron fractional solubility, our data are not conclusive in identifying a clear regional difference with respect to the variability observed for dust collected over the Atlantic Ocean after short- and long-range transport. This limited regional variability suggests that a single reference value $(0.1 \%)$ of the fractional solubility SFe of Saharan and Sahelian dust before atmospheric transport could be used in biogeochemical models. Direct field measurements of $\mathrm{SFe}$ close to emission sources, unavailable at the moment, are needed to confirm this finding. Finally, the SFe value estimated for dust near source regions is in the lowest range, lower than values obtained for dust collected over the Atlantic Ocean, pointing to the need to take atmospheric processing into account when iron solubility is to be described on a global scale.

Acknowledgements. This research was funded by several institutions. Based on a French initiative, AMMA was built by an international scientific group and is currently funded by a large number of agencies, especially from France, the United Kingdom, the United States and Africa. It has been the beneficiary of a major financial contribution from the European Community's Sixth Framework Research Programme. Detailed information on scientific coordination and funding is available on the AMMA International Web site at www.amma-international.org. Financial support by the APIAMMA and LEFE (project BIRD) French national funding programs is also acknowledged. The participation of P. Formenti in the DODO and GERBILS field campaigns was supported by the UK NERC and the UK Met Office; this support is gratefully acknowledged. 
Thanks are also due to the LISA personnel who participated in field campaigns and helped with sample collection, to the BAe-146 and SAFIRE air and ground crews as well as the FAAM and Met Office observers.

Edited by: X. Querol

\section{References}

Abdourhamane Touré, A., Rajot, J. L., Garba, Z., Marticorena, B., Petit, C., and Sebag, D.: Impact of very low crop residues cover on wind erosion in the Sahel. Catena, 85, 205-214. doi:10.1016/j.catena.2011.01.002, 2011.

Alfaro, S. C., Gaudichet, A., Gomes, L., and Maillé, M.: Mineral aerosol production by wind erosion: aerosol particle sizes and binding energies, Geophys. Res. Lett., 25, 991-994, 1998.

Andreae, M. O., Berresheim, H., Andreae, T. W., Kritz, M. A., Bates, T. S., and Merrill, J. T.: Vertical distribution of dimethylsulfide, sulfur dioxide, aerosol ions, and radon over the Northeast Pacific ocean, J. Atmos. Chem., 6, 149-173, 1988.

Ansmann, A., Petzold, A., Kandler, K., Tegen, I. N. A., Wendisch, M., Mümler, D., Weinzierl, B., Müller, T., and Heintzenberg, J.: Saharan Mineral Dust Experiments SAMUM-1 and SAMUM-2: what have we learned?, Tellus B, 63, 403-429, doi:10.1111/j.1600-0889.2011.00555.x, 2011.

Arimoto, R., Balsam, W., and Schloesslin, C.: Visible spectroscopy of aerosol particles collected on filters: iron-oxide minerals, Atmos. Environ., 36, 89-96, 2002.

Atkinson, J. D., Murray, B. J., Woodhouse, M. T., Whale, T. F., Baustian, K. J., Carslaw, K. S., Dobbie, S., O/'Sullivan, D., and Malkin, T. L.: The importance of feldspar for ice nucleation by mineral dust in mixed-phase clouds, Nature, 498, 355-358, doi:10.1038/nature12278, http://www.nature.com/nature/journal/v498/n7454/abs/ nature 12278.html\#supplementary-information, 2013.

Baker, A. R., Jickells, T. D., Witt, M., and Linge, K. L.: Trends in the solubility of iron, aluminium, manganese and phosphorus in aerosol collected over the Atlantic Ocean, Mar. Chem., 98, 4358, doi::10.1016/j.marchem.2005.06.004, 2006.

Balkanski, Y., Schulz, M., Claquin, T., and Guibert, S.: Reevaluation of Mineral aerosol radiative forcings suggests a better agreement with satellite and AERONET data, Atmos. Chem. Phys., 7, 81-95, doi:10.5194/acp-7-81-2007, 2007.

Baron, P. A. and Willeke, K.: Aerosol measurement: Principles, techniques and applications, 2nd Ed., John Wiley and Sons, New York, 883 pp., 2001.

Barthelmy, D.: Mineralogy database, available at: http://www. webmineral.com (last access: 02 January 2014), 2007.

Bedidi, A. and Cervelle, B.: Light scattering by spherical particles with hematite and goethite like optical properties: Effect of water impregnation, J. Geophys. Res., 98, 11941-11952, 1993.

Ben-Ami, Y., Koren, I., and Altaratz, O.: Patterns of North African dust transport over the Atlantic: winter vs. summer, based on CALIPSO first year data, Atmos. Chem. Phys., 9, 7867-7875, doi:10.5194/acp-9-7867-2009, 2009.

Ben-Ami, Y., Koren, I., Rudich, Y., Artaxo, P., Martin, S. T., and Andreae, M. O.: Transport of North African dust from the Bodélé depression to the Amazon Basin: a case study, Atmos. Chem. Phys., 10, 7533-7544, doi:10.5194/acp-10-7533-2010, 2010.
Boucher, O., Randall, D., Artaxo, P., Bretherton, C., Feingold, G., Forster, P., Kerminen, V.-M., Kondo, Y., Liao, H., Lohmann, U., Rasch, P., Satheesh, S. K., Sherwood, S., Stevens, B., and Zhang, X. Y.: Clouds and Aerosols, in: Climate Change 2013: The Physical Science Basis, Contribution of Working Group I to the Fifth Assessment Report of the Intergovernmental Panel on Climate Change, edited by: Stocker, T. F., Qin, D., Plattner, G.-K., Tignor, M., Allen, S. K., Boschung, J., Nauels, A., Xia, Y., Bex, V., and Midgley, P. M., Cambridge University Press, Cambridge, United Kingdom and New York, NY, USA, 2013.

Caquineau, S., Magonthier, M.-C., Gaudichet, A., and Gomes, L.: An improved procedure for the X-ray diffraction analysis of lowmass atmospheric dust samples, Eur. J. Mineral., 9, 157-166, 1997.

Caquineau, S., Gaudichet, A., Gomes, L., and Legrand, M.: Mineralogy of Saharan dust transported over northwestern tropical Atlantic Ocean in relation to source regions, J. Geophys. Res., 107, 4251, doi:10.1029/2000jd000247, 2002.

Carslaw, K. S., Boucher, O., Spracklen, D. V., Mann, G. W., Rae, J. G. L., Woodward, S., and Kulmala, M.: A review of natural aerosol interactions and feedbacks within the Earth system, Atmos. Chem. Phys., 10, 1701-1737, doi:10.5194/acp-10-17012010, 2010.

Chatenet, B., Marticorena, B., Gomes, L., and Bergametti, G.: Assessing the microped size distributions of desert soils erodible by wind, Sedimentology, 43, 901-911, doi:10.1111/j.13653091.1996.tb01509.x, 1996.

Chou, C., Formenti, P., Maille, M., Ausset, P., Helas, G., Harrison, M., and Osborne, S.: Size distribution, shape, and composition of mineral dust aerosols collected during the African Monsoon Multidisciplinary Analysis Special Observation Period 0: Dust and Biomass-Burning Experiment field campaign in Niger, January 2006, J. Geophys. Res., 113, D00C10, doi:10.1029/2008jd009897, 2008.

Christidis, G. E.: Genesis and compositional heterogeneity of smectites, Part III, Alteration of basic pyroclastic rocks - A case study from the Troodos Ophiolite Complex, Cyprus, Am. Mineral., 91, 685-701, 2006.

Christidis, G. E. and Dunham, A. C.: Compositional variations in smectites: Part I, Alteration of intermediate volcanic rocks, A case study from Milos Island, Greece, Clay Minerals, 28, 255273, 1993.

Claquin, T., Schulz, M., and Balkanski, Y. J.: Modeling the mineralogy of atmospheric dust sources, J. Geophys. Res., 104, 22243 22256, 1999.

Crowley, J. N., Ammann, M., Cox, R. A., Hynes, R. G., Jenkin, M. E., Mellouki, A., Rossi, M. J., Troe, J., and Wallington, T. J.: Evaluated kinetic and photochemical data for atmospheric chemistry: Volume V - heterogeneous reactions on solid substrates, Atmos. Chem. Phys., 10, 9059-9223, doi:10.5194/acp-10-90592010, 2010.

Cullen, M. J. P.: The unified forecast/climate model, Meteorol. Mag., 122, 81-93, 1993.

Dai, A.: Drought under global warming: a review, Wiley Interdisciplinary Reviews: Climate Change, 2, 45-65, doi:10.1002/wcc.81, 2011.

Delany, A. C., Parkin, D. W., Griffin, J. J., Goldberg, E. D., and Reinmann, B. E. F.: Airborne dust collected at Barbados, Geochim. Cosmochim. Ac., 31, 885-909, 1967. 
Desboeufs, K. V., Losno, R., and Colin, J. L.: Factors influencing aerosol solubility during cloud processes, Atmos. Environ., 35, 3529-3537, doi:10.1016/S1352-2310(00)00472-6, 2001.

De Souza-Machado, S., Strow, L. L., Motteler, H., and Hannon, S.: Infrared dust spectral signatures from AIRS, Geophys. Res. Lett., 33, L03801, doi:10.1029/2005GL024364, 2006.

Dolcater, D. L., Syers, J. K., and Jackson, M. L.: Titanium as free oxide and substituted forms in kaolinites and other soil minerals, Clays and Clay Minerals, 18, 71-79, 1970.

ECA (Economic Commission for Africa), Assessing sustainable development in Africa, Africa's Sustainable Development Bulletin, Economic Commission for Africa, Addis Ababa, 59 pp., 2005.

Egan, W. G. and Hilgeman, T. W.: Optical Properties of Inhomogeneous Materials: Applications to Geology, Astronomy, Chemistry, and Engineering, Academic Press, 235 pp., 1979.

Flamant, C., Lavaysse, C., Todd, M. C., Chaboureau, J. P., and Pelon, J.: Multi-platform observations of a springtime case of Bodélé and Sudan dust emission, transport and scavenging over west Africa, Q. J. Roy. Meteor. Soc., 135, 413-430, doi:10.1002/qj.376, 2009.

Formenti, P., Elbert, W., Maenhaut, W., Haywood, J., and Andreae, M. O.: Chemical composition of mineral dust aerosol during the Saharan Dust Experiment (SHADE) airborne campaign in the Cape Verde region, September 2000, J. Geophys. Res., 108, 8576, doi:10.1029/2002jd002648, 2003.

Formenti, P., Rajot, J. L., Desboeufs, K., Caquineau, S., Chevaillier, S., Nava, S., Gaudichet, A., Journet, E., Triquet, S., Alfaro, S., Chiari, M., Haywood, J., Coe, H., and Highwood, E.: Regional variability of the composition of mineral dust from western Africa: Results from the AMMA SOP0/DABEX and DODO field campaigns, J. Geophys. Res., 113, D00C13, doi:10.1029/2008jd009903, 2008.

Formenti, P., Nava, S., Prati, P., Chevaillier, S., Klaver, A., Lafon, S., Mazzei, F., Calzolai, G., and Chiari, M.: Self-attenuation artifacts and correction factors of light element measurements by $\mathrm{X}$-ray analysis: Implication for mineral dust composition studies, J. Geophys. Res., 115, D01203, doi:10.1029/2009jd012701, 2010.

Formenti, P., Schütz, L., Balkanski, Y., Desboeufs, K., Ebert, M., Kandler, K., Petzold, A., Scheuvens, D., Weinbruch, S., and Zhang, D.: Recent progress in understanding physical and chemical properties of African and Asian mineral dust, Atmos. Chem. Phys., 11, 8231-8256, doi:10.5194/acp-11-8231-2011, 2011a.

Formenti, P., Rajot, J. L., Desboeufs, K., Saïd, F., Grand, N., Chevaillier, S., and Schmechtig, C.: Airborne observations of mineral dust over western Africa in the summer Monsoon season: spatial and vertical variability of physico-chemical and optical properties, Atmos. Chem. Phys., 11, 6387-6410, doi:10.5194/acp-11-6387-2011, 2011 b.

Formenti, P., Caquineau, S., Chevaillier, S., Klaver, A., Desboeufs, K., Rajot, J. L., Belin, S. and Briois, V.: Dominance of goethite over hematite in iron oxides of mineral dust from western Africa: quantitative partitioning by X-ray Absorption Spectroscopy, J. Geophys. Res., accepted, 2014.

Gillette, D. and Walker, T. R.: Characteristics of airborne particles produced by wind erosion of sandy soil, high plains of west Texas, Soil Sci., 123, 97-110, 1977.

Ginoux, P., Prospero, J. M., Gill, T. E., Hsu, N. C., and Zhao, M.: Global-scale attribution of anthropogenic and nat- ural dust sources and their emission rates based on MODIS Deep Blue aerosol products, Rev. Geophys., 50, RG3005, doi:10.1029/2012RG000388, 2012.

Glaccum, R. A. and Prospero, J. M.: Saharan aerosols over the tropical north Atlantic - mineralogy, Marine Geology, 37, 295-321, 1980.

Glotch, T. D. and Rossman, G. R.: Mid-infrared reflectance spectra and optical constants of six iron oxide/oxyhydroxide phases, Icarus, 204, 663-671, 2009.

Glotch, T. D., Rossman, G. R., and Aharonson, O.: Midinfrared $(5-100 \mu \mathrm{m})$ reflectance spectra and optical constants of ten phyllosilicate minerals, Icarus, 192, 604-622, doi:10.1016/j.icarus.2007.07.002, 2007.

Goudie, A. S. and Middleton, N. J.: Saharan dust storms: nature and consequences, Earth-Sci. Rev., 56, 179-204, 2001.

Gustafsson, R. J., Orlov, A., Griffiths, P. T., Cox, R. A., and Lambert, R. M.: Reduction of $\mathrm{NO}_{2}$ to nitrous acid on illuminated titanium dioxide aerosol surfaces: implications for photocatalysis and atmospheric chemistry, Chem. Commun., 1359-7345, 39363938, 2006.

Hand, J. L., Mahowald, N. M., Chen, Y., Siefert, R. L., Luo, C., Subramaniam, A., and Fung, I.: Estimates of atmosphericprocessed soluble iron from observations and a global mineral aerosol model: Biogeochemical implications, J. Geophys. Res., 109, D17205, doi:10.1029/2004JD004574, 2004.

Hansell Jr., R. A., Reid, J. S., Tsay, S. C., Roush, T. L., and Kalashnikova, O. V.: A sensitivity study on the effects of particle chemistry, asphericity and size on the mass extinction efficiency of mineral dust in the earth's atmosphere: from the near to thermal IR, Atmos. Chem. Phys., 11, 1527-1547, doi:10.5194/acp-111527-2011, 2011.

Haywood, J. M., Allan, R. P., Culverwell, I., Slingo, T., Milton, S., Edwards, J., and Clerbaux, N.: Can desert dust explain the outgoing longwave radiation anomaly over the Sahara during July 2003?, J. Geophys. Res., 110, D05105, doi:10.1029/2004JD005232, 2005.

Haywood, J. M., Pelon, J., Formenti, P., Bharmal, N., Brooks, M., Capes, G., Chazette, P., Chou, C., Christopher, S., Coe, H., Cuesta, J., Derimian, Y., Desboeufs, K., Greed, G., Harrison, M., Heese, B., Highwood, E. J., Johnson, B., Mallet, M., Marticorena, B., Marsham, J., Milton, S., Myhre, G., Osborne, S. R., Parker, D. J., Rajot, J. L., Schulz, M., Slingo, A., Tanré, D., and Tulet, P.: Overview of the Dust and Biomass-burning Experiment and African Monsoon Multidisciplinary Analysis Special Observing Period-0, J. Geophys. Res., 113, D00C17, doi:10.1029/2008jd010077, 2008.

Haywood, J. M., Johnson, B. T., Osborne, S. R., Baran, A. J., Brooks, M., Milton, S. F., Mulcahy, J., Walters, D., Allan, R. P., Klaver, A., Formenti, P., Brindley, H. E., Christopher, S., and Gupta, P.: Motivation, rationale and key results from the GERBILS Saharan dust measurement campaign, Q. J. Roy. Meteor. Soc., 137, 1106-1116, doi:10.1002/qj.797, 2011.

Heintzenberg, J.: The SAMUM-1 experiment over Southern Morocco: overview and introduction, Tellus B, 61, 2-11, doi:10.1111/j.1600-0889.2008.00403.x, 2009.

Hess, M., Koepke, P., and Schult, I.: Optical properties of aerosols and clouds: The software package OPAC, Bull. Am. Meteorol. Soc, 79, 831-844, 1998. 
Highwood, E. J., Haywood, J. M., Silverstone, M. D., Newman, S. M., and Taylor, J. P.: Radiative properties and direct effect of Saharan dust measured by the C-130 aircraft during Saharan Dust Experiment (SHADE): 2. Terrestrial spectrum, J. Geophys. Res., 108, 8578, doi:10.1029/2002JD002552, 2003.

Hinds, W. C.: Aerosol technology: properties, behavior, and measurement of airborne particles, John Wiley and Sons, Chichester, 504 pp., 1999.

Hoose, C., Lohmann, U., Erdin, R., and I. Tegen: The global influence of dust mineralogical composition on heterogeneous ice nucleation in mixed-phase clouds, Environ. Res. Lett., 3, 025003, doi:10.1088/1748-9326/3/2/025003, 2008.

Hudson, P. K., Gibson, E. R., Young, M. A., Kleiber, P. D., and Grassian, V. H.: Coupled infrared extinction and size distribution measurements for several clay components of mineral dust aerosol, J. Geophys. Res., 113, D01201, doi:10.1029/2007JD008791, 2008a.

Hudson, P. K., Young, M. A., Kleiber, P. D., and Grassian, V. H.: coupled infrared extinction spectra and size distribution measurements for several non-clay components of mineral dust aerosol (quartz, calcite, and dolomite), Atmos. Environ., 42, 5991-5999, 2008b.

Huneeus, N., Schulz, M., Balkanski, Y., Griesfeller, J., Prospero, J., Kinne, S., Bauer, S., Boucher, O., Chin, M., Dentener, F., Diehl, T., Easter, R., Fillmore, D., Ghan, S., Ginoux, P., Grini, A., Horowitz, L., Koch, D., Krol, M. C., Landing, W., Liu, X., Mahowald, N., Miller, R., Morcrette, J.-J., Myhre, G., Penner, J., Perlwitz, J., Stier, P., Takemura, T., and Zender, C. S.: Global dust model intercomparison in AeroCom phase I, Atmos. Chem. Phys., 11, 7781-7816, doi:10.5194/acp-11-7781-2011, 2011.

Janicot, S., Thorncroft, C. D., Ali, A., Asencio, N., Berry, G., Bock, O., Bourles, B., Caniaux, G., Chauvin, F., Deme, A., Kergoat, L., Lafore, J.-P., Lavaysse, C., Lebel, T., Marticorena, B., Mounier, F., Nedelec, P., Redelsperger, J.-L., Ravegnani, F., Reeves, C. E., Roca, R., de Rosnay, P., Schlager, H., Sultan, B., Tomasini, M., Ulanovsky, A., and ACMAD forecasters team: Large-scale overview of the summer monsoon over west Africa during the AMMA field experiment in 2006, Ann. Geophys., 26, 25692595, doi:10.5194/angeo-26-2569-2008, 2008.

Jeong, G. Y.: Bulk and single-particle mineralogy of Asian dust and a comparison with its source soils, J. Geophys. Res., 113, D02208, doi:10.1029/2007JD008606, 2008.

Johnson, B. T., Osborne, S. R., Haywood, J. M., and Harrison, M. A. J.: Aircraft measurements of biomass burning aerosol over west Africa during DABEX, J. Geophys. Res., 113, D00C06, doi:10.1029/2007jd009451, 2008.

Journet, E., Desboeufs, K. V., Caquineau, S., and Colin, J.-L.: Mineralogy as a critical factor of dust iron solubility, Geophys. Res. Lett., 35, L07805, doi:10.1029/2007g1031589, 2008.

Journet, E., Balkanski, Y., and Harrison, S. P.: A new data set of soil mineralogy for dust-cycle modeling, Atmos. Chem. Phys., 14, 3801-3816, doi:10.5194/acp-14-3801-2014, 2014.

Kandler, K., Schütz, L., Deutscher, C., Ebert, M., Hofmann, H., Jäckel, S., Jaenicke, R., Knippertz, P., Lieke, K., Massling, A., Petzold, A., Schladitz, A., Weinzierl, B., Wiedensohler, A., Zorn, S., and Weinbruch, S.: Size distribution, mass concentration, chemical and mineralogical composition and derived optical parameters of the boundary layer aerosol at Tinfou, Morocco, dur- ing SAMUM 2006, Tellus B, 61, 32-50, doi:10.1111/j.16000889.2008.00385.x, 2009.

Karickhoff, S. W. and Bailey, G. W.: Optical absorption spectra of clay minerals, Clays Clay Min., 21, 59-70, 1973.

Kiefert, L., McTainsh, G. H., and Nickling, W. G.: Sedimentological characteristics of Saharan and Australian dust, in: The Impact of Desert Dust Across the Mediterranean, edited by: Guerzoni, S. and Chester, R., 183-190, Kluwer Acad., Norwell, Mass., 1996.

Klaver, A., Formenti, P., Caquineau, S., Chevaillier, S., Ausset, P., Calzolai, G., Osborne, S., Johnson, B., Harrison, M., and Dubovik, O.: Physico-chemical and optical properties of Sahelian and Saharan mineral dust: in situ measurements during the GERBILS campaign, Q. J. Roy. Meteor. Soc., 137, 1193-1210, doi:10.1002/qj.889, 2011.

Klaver, A.: Estimation des propriétés optiques des poussières désertiques d'origines saharienne et sahélienne, à proximité de leurs zones sources d'émission, à partir de leurs propriétés physicochimiques, thèse de Doctorat, Université Paris VII, 2012.

Klüser, L., Martynenko, D., and Holzer-Popp, T.: Thermal infrared remote sensing of mineral dust over land and ocean: a spectral SVD based retrieval approach for IASI, Atmos. Meas. Tech., 4, 757-773, doi:10.5194/amt-4-757-2011, 2011.

Klüser, L., Kleiber, P., Holzer-Popp, T., Grassian, V. H.: Desert Dust Observation From Space - Application of Measured Mineral Component Infrared Extinction Spectra, Atmos. Environ., 54, 419-427, 2012.

Koren, I., Kaufman, Y. J., Washington, R., Todd, M. C., Rudich, Y., Vanderlei Martins, J., and Rosenfeld, D.: The Bodélé depression: a single spot in the Sahara that provides most of the mineral dust to the Amazon forest, Environ. Res. Lett., 1, 014005 , doi:10.1088/1748-9326/1/1/014005, 2006.

Köster, H. M., Ehrlicher, U., Gilg, H. A., Jordan, R., Murad, E., and Onnich, K.: Mineralogical and chemical characteristics of five nontronites and Fe-rich smectites, Clay Minerals, 34, 579-599, 1999.

Lafon, S., Rajot, J., Alfaro, S., and Gaudichet, A.: Quantification of iron oxides in desert aerosol., Atmos. Environ., 38, 1211-1218, 2004.

Lafon, S., Sokolik, I. N., Rajot, J. L., Caquineau, S., and Gaudichet, A.: Characterization of iron oxides in mineral dust aerosols: Implications for light absorption, J. Geophys. Res., 111, D21207, doi:10.1029/2005jd007016, 2006.

Laskina, O., Young, M. A., Kleiber, P. D., and Grassian, V. H.: Infrared extinction spectra of mineral dust aerosol: Single components and complex mixtures, J. Geophys. Res., 117, D18210, doi:10.1029/2012JD017756, 2012.

Laurent, B., Marticorena, B., Bergametti, G., Léon, J. F., and Mahowald, N. M.: Modeling mineral dust emissions from the Sahara desert using new surface properties and soil database, J. Geophys. Res., 113, D14218, doi:10.1029/2007jd009484, 2008.

Lazaro, F. J., Gutiérrez, L., Barrón, V., and Gelado, M. D.: The speciation of iron in desert dust collected in Gran Canaria (Canary Islands): Combined chemical, magnetic and optical analysis, Atmos. Environ., 42, 8987-8996, 2008.

Lebel, T., Parker, D. J., Flamant, C., Bourlès, B., Marticorena, B., Mougin, E., Peugeot, C., Diedhiou, A., Haywood, J. M., Ngamini, J. B., Polcher, J., Redelsperger, J. L., and Thorncroft, C. D.: The AMMA field campaigns: multiscale and multidisci- 
plinary observations in the west African region, Q. J. Roy. Meteor. Soc., 136, 8-33, doi:10.1002/qj.486, 2010.

Legrand, M., N'doumé, C., and Jankowiak, I.: Satellite-derived climatology of the Saharan aerosol., in: Passive Infrared Remote Sensing of Clouds and the Atmosphere II, edited by: Lynch, D. K., SPIE, 127-135, 1994.

Lepple, F. K. and Brine, C. J.: Organic constituents in eolian dust and surface sediments from northwest Africa, J. Geophys. Res., 81, 1141-1147, 1976.

Long, L. L., Querry, M. R., Bell, R. J., and Alexander, R. W.: Optical properties of calcite and gypsum in crystalline and powdered form in the infrared and far-infrared, Infrared Physics, 34, 191201, 1993.

Longtin, D. R., Shettle, E. P., Hummel, J. R., Pryce, J. D.: A Wind Dependent Desert Aerosol Model: Radiative Properties. AFGLTR-88-0112, Air Force Geophysics Laboratory, Hanscom AFB, MA, 1988.

Mahowald, N.: Aerosol indirect effects on biogeochemistry and climate, Science, 334, 794, doi:10.1126/science.1207374, 2011.

Majestic, B. J., Schauer, J. J., and Shafer, M. M.: Application of synchrotron radiation for measurement of iron red-ox speciation in atmospherically processed aerosols, Atmos. Chem. Phys., 7, 2475-2487, doi:10.5194/acp-7-2475-2007, 2007.

Marra, A. C., Blanco, A., Fonti, S., Jurewicz, A., and Orofino, V.: Fine hematite particles of Martian interest: absorption spectra and optical constants, Journal of Physics, Conference Series, 6, 132-138, 2005.

Marticorena, B. and Bergametti, G.: Modeling the atmospheric dust cycle: 1 . Design of a soil-derived dust emission scheme, J. Geophys. Res., 100, 16415-16430, doi:10.1029/95jd00690, 1995.

Marticorena, B., Chatenet, B., Rajot, J. L., Traoré, S., Coulibaly, M., Diallo, A., Koné, I., Maman, A., NDiaye, T., and Zakou, A.: Temporal variability of mineral dust concentrations over west Africa: analyses of a pluriannual monitoring from the AMMA Sahelian Dust Transect, Atmos. Chem. Phys., 10, 8899-8915, doi:10.5194/acp-10-8899-2010, 2010.

Mason, B.: Principles of Geochemistry, 3rd Ed., John Wiley, New York, 276 pp., 1966.

McConnell, C. L., Highwood, E. J., Coe, H., Formenti, P., Anderson, B., Osborne, S., Nava, S., Desboeufs, K., Chen, G., and Harrison, M. A. J.: Seasonal variations of the physical and optical characteristics of Saharan dust: Results from the Dust Outflow and Deposition to the Ocean (DODO) experiment, J. Geophys. Res., 113, D14S05, doi:10.1029/2007jd009606, 2008.

McConnell, C. L., Formenti, P., Highwood, E. J., and Harrison, M. A. J.: Using aircraft measurements to determine the refractive index of Saharan dust during the DODO Experiments, Atmos. Chem. Phys., 10, 3081-3098, doi:10.5194/acp-10-30812010, 2010.

Mehra, O. P. and Jackson, M. L.: Iron oxide removal from soils and clays by a dithionite-citrate buffered with sodium bicarbonate, Clay Minerals, 7, 317-327, 1960.

Mestdagh, M. M., Vielvoye, L., and Herbillon, A. J.: Iron in Kaolinite: The relationship between kaolinite crystallinity and iron content, Clay Minerals, 15, 1-13, 1980.

Mogili, P. K., Yang, K. H., Young, M. A., Kleiber, P. D., and Grassian, V. H.: Environmental aerosol chamber studies of extinction spectra of mineral dust aerosol components: Broadband IR-
UV extinction spectra, J. Geophys. Res.-Atmos., 112, D21204, doi:10.1029/2007jd008890, 2007.

Mogili, P. K., Yang, K. H., Young, M. A., Kleiber, P. D., and Grassian, V. H.: Extinction spectra of mineral dust aerosol components in an environmental aerosol chamber: IR resonance studies, Atmos. Environ., 42, 1752-1761, doi:10.1016/j.atmosenv.2007.11.026, 2008.

Mooney, T. and Knacke, R. F.: Optical Constants of Chlorite and Serpentine between 2.5 and $50 \mu \mathrm{m}$, Icarus, 64, 493-502, 1985.

Moreno, T., Querol, X., Castillo, S., Alastuey, A., Cuevas, E., Herrmann, L., Mounkaila, M., Elvira, J., and Gibbons, W.: Geochemical variations in aeolian mineral particles from the Sahara-Sahel Dust Corridor, Chemosphere, 65, 261-270, doi::10.1016/j.chemosphere.2006.02.052, 2006.

Murad, E. and Wagner, U.: The Mossbauer spectrum of illite, Clay Minerals, 29, 1-10, 1994.

Ndour, M., D’Anna, B., George, C., Ka, O., Balkanski, Y., Kleffmann, J., Stemmler, K., and Ammann, M.: Photoenhanced uptake of $\mathrm{NO}_{2}$ on mineral dust: Laboratory experiments and model simulations, Geophys. Res. Lett., 35, doi:10.1029/2007GL032006, 2008.

Nickovic, S., Vukovic, A., Vujadinovic, M., Djurdjevic, V., and Pejanovic, G.: Technical Note: High-resolution mineralogical database of dust-productive soils for atmospheric dust modeling, Atmos. Chem. Phys., 12, 845-855, doi:10.5194/acp-12-8452012, 2012.

N'Tchayi, G. M., Bertrand, J., Legrand, M., and Baudet, J.: Temporal and spatial variations of the atmospheric dust loading throughout west Africa over the last thirty years, Ann. Geophys., 12, 265-273, doi:10.1007/s00585-994-0265-3, 1994.

N'Tchayi, G. M., Bertrand, J., and Nicholson, S. E.: The diurnal and seasonal cycles of wind-borne dust over Africa north of the equator, J. Appl. Meteor., 36, 868-882, 1997.

Ohta, A., Tsuno, H., Kagi, H., Kanai, Y., Nomura, M., Zhang, R., Terashima, N., and Imai, N.: Chemical compositions and XANES speciations of Fe, $\mathrm{Mn}$ and $\mathrm{Zn}$ from aerosols collected in China and Japan during dust events, Geochem. J., 40, 363-376, 2006.

Paquet, H., Coudé-Gaussen, G., and Rognon, P.: Etude minéralogique de poussières sahariennes le long d'un itinéraire entre $19^{\circ}$ et $35^{\circ}$ de latitude nord, Révue de Géologie Dynamique et de Géographie Physique, 25, 257-265, 1984.

Paris, R. and Desboeufs, K. V.: Effect of atmospheric organic complexation on iron-bearing dust solubility, Atmos. Chem. Phys., 13, 4895-4905, doi:10.5194/acp-13-4895-2013, 2013.

Paris, R., Desboeufs, K. V., and Journet, E.: Variability of dust iron solubility in atmospheric waters: Investigation of the role of oxalate organic complexation, Atmos. Environ., 45, 6510-6517, doi:10.1016/j.atmosenv.2011.08.068, 2011.

Pentrakova, L., Su, K., Pentak, M., and Stucki, J. W.: A review of microbial redox interactions with structural Fe in clay minerals, Clay Minerals, 48, 543-560, 2013.

Peterson, J. T. and Weinman, J. A.: Optical properties of quartz dust particles at infrared wavelengths, J. Geophys. Res., 74, 69476952, 1969.

Prietzel, J., Thieme, J., Eusterhues, K., and Eichert, D.: Iron speciation in soils and soil aggregates by synchrotron-based $\mathrm{x}$. ray microspectroscopy (xanes, mu-xanes), Eur. J. Soil. Sci., 58, 10271041, 2007. 
Prospero, J. M., Ginoux, P., Torres, O., Nicholson, S. E., and Gill, T. E.: Environmental characterization of global sources of atmospheric soil dust identified with the Nimbus 7 Total Ozone Mapping Spectrometer (TOMS) absorbing aerosol product., Rev. Geophys., 40, 2-1-2-31, 2002.

Pye, K.: Aeolian Dust and Dust Deposits, Academic Press, London, 334 pp., 1987.

Querry, M. R.: Optical constants of minerals and other materials from the millimeter to the UV. U.S. Army Rep. CRDEC-CR88009, Aberdeen, MD, 1987.

Querry, M. R., Osborne, G., Lies, K., Jordon, R., and Coveney, R. M.: Complex refractive index of limestone in the visible and infrared, Applied Optics, 17, 353-356, 1978.

Rahn, K. A.: Silicon and aluminum in atmospheric aerosols: crustair fractionation?, Atmos. Environ., 10, 597-601, 1976.

Rajot, J.-L.: Wind blown sediment mass budget of Sahelian village land units in Niger., Bull. Soc. Géol, France, 172, 523-531, 2001.

Rajot, J.-L., Formenti, P., Alfaro, S., Desboeufs, K., Chevaillier, S., Chatenet, B., Gaudichet, A., Journet, E., Marticorena, B., Triquet, S., Maman, A., Mouget, N., and Zakou, A.: AMMA dust experiment: An overview of measurements performed during the dry season special observation period (SOP0) at the Banizoumbou (Niger) supersite, J. Geophys. Res., 113, D00C14, doi:10.1029/2008jd009906, 2008.

Redelsperger, J.-L., Thorncroft, C. D., Diedhiou, A., Lebel, T., Parker, D. J., and Polcher, J.: African Monsoon Multidisciplinary Analysis: An International Research Project and Field Campaign, B. Am. Meteorol. Soc., 87, 1739-1746, doi:10.1175/BAMS-87-12-1739, 2006.

Reeves, C. E., Formenti, P., Afif, C., Ancellet, G., Attié, J.-L., Bechara, J., Borbon, A., Cairo, F., Coe, H., Crumeyrolle, S., Fierli, F., Flamant, C., Gomes, L., Hamburger, T., Jambert, C., Law, K. S., Mari, C., Jones, R. L., Matsuki, A., Mead, M. I., Methven, J., Mills, G. P., Minikin, A., Murphy, J. G., Nielsen, J. K., Oram, D. E., Parker, D. J., Richter, A., Schlager, H., Schwarzenboeck, A., and Thouret, V.: Chemical and aerosol characterisation of the troposphere over west Africa during the monsoon period as part of AMMA, Atmos. Chem. Phys., 10, 7575-7601, doi:10.5194/acp-10-7575-2010, 2010.

Reid, E. A., Reid, J. S., Meier, M. M., Dunlap, M. R., Cliff, S. S., Broumas, A., Perry, K., and Maring, H.: Characterization of African dust transported to Puerto Rico by individual particle and size segregated bulk analysis, J. Geophys. Res., 108, 8591, doi:10.1029/2002jd002935, 2003.

Roush, T., Pollack, J., and Orenberg, J.: Derivation of midinfrared $(5-25 \mu \mathrm{m})$ optical constants of some silicates and palagonite, Icarus, 94, 191-208. doi:10.1016/0019-1035(91)90150-R, 1991.

Saïd, F., Canut, G., Durand, P., Lohou, F., and Lothon, M.: Seasonal evolution of boundary-layer turbulence measured by aircraft during the AMMA 2006 Special Observation Period, Q. J. Roy. Meteor. Soc., 136, 47-65, doi:10.1002/qj.475, 2010.

Sarthou, G., Baker, A. R., Blain, S., Achterberg, E. P., Boye, M., Bowie, A. R., Croot, P., Laan, P., de Baar, H. J. W., Jickells, T. D., and Worsfold, P. J.: Atmospheric iron deposition and sea-surface dissolved iron concentrations in the eastern Atlantic Ocean, Deep Sea Research Part I: Oceanographic Research Papers, 50, 13391352, doi::10.1016/S0967-0637(03)00126-2, 2003.
Schepanski, K., Tegen, I., and Macke, A.: Comparison of satellite based observations of Saharan dust source areas, Remote Sens. Environ., 123, 90-97, 2012.

Scheuvens, D., Schütz, L., Kandler, K., Ebert, M., and Weinbruch, S.: Bulk composition of northern African dust and its source sediments - A compilation, Earth-Sci. Rev., 116, 170194, doi:10.1016/j.earscirev.2012.08.005, 2013.

Schroth, A. W., Crusius, J., Sholkovitz, E. R., and Bostick, B. C.: Iron solubility driven by speciation in dust sources to the ocean, Nature Geosci., 2, 337-340, 2009.

Shao, Y., Wyrwoll, K.-H., Chappell, A., Huang, J., Lin, Z., McTainsh, G. H., Mikami, M., Tanaka, T. Y., Wang, X., and Yoon, S.: Dust cycle: An emerging core theme in Earth system science, Aeolian Research, 2, 181-204, doi:10.1016/j.aeolia.2011.02.001, 2011.

Shettle, E. P. and Fenn, R. W.: Models for the Aerosols of the Lower Atmosphere and the Effects of Humidity Variations on Their Optical Properties, AFGL-TR-79-0214, ADA085951, 1979.

Shi, Z., Krom, M. D., Bonneville, S., Baker, A. R., Bristow, C., Drake, N., Mann, G., Carslaw, K., McQuaid, J. B., Jickells, T., and Benning, L. G.: Influence of chemical weathering and aging of iron oxides on the potential iron solubility of Saharan dust during simulated atmospheric processing, Global Biogeochem. Cy., 25, GB2010, doi:10.1029/2010GB003837, 2011.

Sholkovitz, E. R., Sedwick, P. N., Church, T. M., Baker, A. R., and Powell, C. F.: Fractional solubility of aerosol iron: Synthesis of a global-scale data set, Geochim. Cosmochim. Ac., 89, 173-189, doi:10.1016/j.gca.2012.04.022, 2012.

Smith, A. J. A. and Grainger, R. G.: Does variation in mineral composition alter the short-wave light scattering properties of desert dust aerosol?, J. Quant. Spectrosc. Radiat. Transfer, 133, 235243, doi:10.1016/j.jqsrt.2013.08.005, 2014.

Sokolik, I. and Toon, O.: Incorporation of mineralogical composition into models of the radiative properties of mineral aerosol from UV to IR wavelengths, J. Geophys. Res., 104, 9423-9444, 1999.

Sokolik, I. N., Toon, O. B., and Bergstrom, R. W.: Modeling the radiative characteristics of airborne mineral aerosols at infrared wavelengths, J. Geophys. Res., 103, 8813-8826, 1998.

Sokolik, I. N., Winker, D. M., Bergametti, G., Gillette, D. A., Carmichael, G., Kaufman, Y. J., Gomes, L., Schuetz, L., and Penner, J. E.: Introduction to special section: Outstanding problems in quantifying the radiative impacts of mineral dust, J. Geophys. Res., 106, 18015-18027, doi:10.1029/2000jd900498, 2001.

Sow, M., Alfaro, S. C., Rajot, J. L., and Marticorena, B.: Size resolved dust emission fluxes measured in Niger during 3 dust storms of the AMMA experiment, Atmos. Chem. Phys., 9, 38813891, doi:10.5194/acp-9-3881-2009, 2009.

Spitzer, W. G. and Kleinman, D. A.: Infrared lattice bands of quartz, Physical Review, 121, 1324-1335, 1961.

Tegen, I. and Fung, I.: Modeling of mineral dust in the atmosphere: Sources, transport, and optical thickness, J. Geophys. Res., 99, 22897-22914, 1994.

Toon, O. B., Pollock, J. B., and Khare, B. N.: The optical constants of several atmospheric aerosols species: ammonium sulfate, aluminum oxide and sodium chloride, J. Geophys. Res. Lett., 81, 5733-5748, 1976.

Tulet, P., Mallet, M., Pont, V., Pelon, J. and Boone, A.: The 713 March 2006 dust storm over west Africa: Generation, trans- 
port, and vertical stratification, J. Geophys. Res., 113, D00C08, doi:10.1029/2008JD009871, 2008.

Washington, R., Todd, M. C., Engelstaedter, S., Mbainayel, S., and Mitchell, F.: Dust and the low-level circulation over the Bodélé Depression, Chad: Observations from BoDEx 2005, J. Geophys. Res., 111, D03201, doi:10.1029/2005jd006502, 2006.

Washington, R., Flamant, C., Parker, D. J., Marsham, J., McQuaid, J. B., Brindley, H., Todd, M., Highwood, E. J., Ryder, C. L., Chaboreau, J.-P., Kocha, C., Bechir, M., and Saci, A.: Fennec - The Saharan Climate System, No. 60, Vol. 17, No. 3, 31-32, CLIVAR Exchanges, 2012.
Wilke, M., Farges, F., Petit, P.-E., Brown, G. E. J., and Mertin, F.: Oxidation state and coordination of $\mathrm{Fe}$ in minerals: An Fe KXANES spectroscopic study, Am. Mineral., 86, 714-730, 2001.

Yoshioka, M., Mahowald, N., Dufresne, J.-L., and Luo, C.: Simulation of absorbing aerosol indices for African dust, J. Geophys. Res., 110, D18S17, doi:10.1029/2004jd005276, 2005. 